\title{
Archipel
}

ARCHIPEL Études interdisciplinaires sur le monde insulindien

$99 \mid 2020$

Varia

\section{Rediscovering an Old Javanese Inscription: Mpu Mano's Donation in Favor of a Buddhist Dignitary in 888 Śaka}

Redécouverte d'une inscription en vieux javanais : la donation de Mpu Mano en faveur d'un dignitaire bouddhiste en 888 Śaka

\section{Arlo Griffiths}

\section{OpenEdition}

\section{Journals}

\section{Electronic version}

URL: http://journals.openedition.org/archipel/1976

DOI: 10.4000/archipel. 1976

ISSN: 2104-3655

\section{Publisher}

Association Archipel

\section{Printed version}

Date of publication: 15 July 2020

Number of pages: 107-141

ISBN: 978-2-910513-83-2

ISSN: 0044-8613

\section{Electronic reference}

Arlo Griffiths, "Rediscovering an Old Javanese Inscription: Mpu Mano's Donation in Favor of a Buddhist Dignitary in 888 Śaka", Archipel [Online], 99 | 2020, Online since 02 June 2020, connection on 15 March 2021. URL: http://journals.openedition.org/archipel/1976 ; DOI: https://doi.org/10.4000/archipel.1976 


\section{Rediscovering an Old Javanese Inscription: Mpu Mano's Donation in Favor of a Buddhist Dignitary in 888 Śaka}

"Tugas seorang ahli epigrafi sekarang ini tidak saja meneliti prasasti-prasasti yang belum diterbitkan, tetapi juga meneliti kembali prasasti-prasasti yang baru terbit dalam transkripsi sementara. Kemudian ia harus menerjemahkan prasasti-prasasti tersebut ke dalam bahasa modern sehingga sarjana-sarjana yang lain, terutama ahli-ahli sejarah dapat menggunakan keterangan-keterangan yang terkandung di dalam prasasti-prasasti itu." (Boechari 1977: 3 / 2012: 5)

\section{Introduction}

Of the inscription that will occupy us in these pages, so far only the opening paragraphs are known to scholarship in the form of the first of what must have been a set of copper plates on which the inscription, originally issued in 888 Śaka (966 CE), was reissued in the Majapahit period. The remaining plates of this set have never been found, nor has any trace been discovered of the

1. École française d'Extrême-Orient, Paris ; UMR 5189, Histoire et Sources des Mondes Antiques, Lyon ; <arlo.griffiths@efeo.net>. My thanks are due to Henri Chambert-Loir for encouraging me to finally write up some of the results of a decade that I have spent working on Old Javanese inscriptions without publishing much about them. The research for this article has been undertaken as part of the project DHARMA "The Domestication of "Hindu" Asceticism and the Religious Making of South and Southeast Asia', funded by the European Research Council (ERC) under the European Union's Horizon 2020 research and innovation programme (grant agreement no 809994). See https://dharma.hypotheses.org. I thank my fellow project members Timothy Lubin, Annette Schmiedchen and Marine Schoettel for their comments on an earlier draft. I also thank Nigel Bullough (alias Hadi Sidomulyo) and Jan Wisseman Christie for the useful comments that they furnished as reviewers for this journal. 
original inscription that must have been issued on stone or copper-plate in the 10 th century. ${ }^{2}$

Although the publication of an edition with translation was announced by H. Kern (1908: 51), this plan never materialized (Kern 1917b: 185 n. 2). Rather, it is among the transcriptions left by J.L. Brandes after his death and edited by N.J. Krom in 1913 under the title Oud-Javaansche Oorkonden $(O J O)$ that we find the only edition ever published. In that collection, it is item no. LV. To my knowledge, no integral translation has ever been published.

In his introductory note, as editor of Brandes' work, Krom explains that the reading of the inscription had been done on the basis of a set of rubbings. He refers to the Notulen van de Algemeene en Bestuursvergaderingen van het Bataviaasch Genootschap van Kunsten en Wetenschappen ( $N B G)$ vol. XXXVI (1898), pp. 102, 153, 181, and quotes at length from pages 122-123, where Brandes had summarized the contents of the plate noting its connections with what is known to scholarship today as the Sobhamerta inscription dated to 861 Śaka. ${ }^{3}$ A religious master named Mpunku i Nairañjana figures in both, as does the term podga ${ }^{2} i k a$. Brandes also remarked that both inscriptions, dated within 27 years the one from the other in the 10th century CE, show a script form that appears considerably younger than the period to which they are dated, in other words that both would be later reissues of grants originally issued in the 10th century, and refers in this connection to the evidence from the Deśavarnana that reissuing of earlier grants took place on a large scale during the reign of Hayam Wuruk in the 14 th century. ${ }^{4}$

Krom $(O J O$, p. 116) states that the plate was said to have been found at Trowulan. It was held by Haji Doolkarim, a resident of Kepanjen near Malang, when it was first mentioned in the scholarly literature in $1898 .{ }^{5}$ Subsequently, it came into the hands of a certain Mr. Wiederhold who resided at Malang. While it was in Wiederhold's hands, a reproduction was sent to H. Kern which allowed him to read the inscription and comment on its contents (Kern 1908, 1911). The original plate was shown by Wiederhold to N.J. Krom in $1912 .{ }^{6}$

2. Cases where we do have both are rare. One of them is the Cunggrang inscription, for which we have the original stone and a Majapahit-period reissue.

3. Damais 1952: 60-61, 1955: 60; Nakada 1982: 104-105 (entry no. 142); Titi Surti Nastiti 2007.

4. See Damais 1951: 31-32, essentially repeating Brandes' remarks in OJO LV, but adding in a note that the Năgarakrtagama, nowadays more appropriately called Deśavarnana by most scholars, "indique expressément que Hayam Wuruk, au cours de son voyage dans l'île, renouvela plusieurs privilèges tombés plus ou moins en désuétude", with particular reference to stanza 73.2.

5. See $N B G$ 1898, esp. p. 181.

6. See Oudheidkundig Verslag 1912, p. 62: "Door bemiddeling van den Heer van Hinloopen Labberton te Buitenzorg kreeg ik inzage van een drietal koperplaten en afschriften van nog vier andere, de eerste in bezit van den Heer Wiederhold te Malang, de laatste in het bezit van dienzelfden, van Mr. Krüseman en van den Heer Römer te Soerabaja. Eén daarvan, gedateerd 888, bleek de reeds door Dr. Brandes behandelde, in Notulen Bat. Gen. 1898 (p. 102, 122, 153, 181) besprokene te zijn. De overige 
After it was seen by Krom, the plate has come to be considered lost, and this is the main reason why it has never been restudied. ${ }^{7}$ But my documentation since 2008 of the epigraphic collections of Indonesian inscriptions kept in the Netherlands in the framework of the collaboration between the Pusat Penelitian Arkeologi Nasional and the EFEO to compile an inventory of ancient inscriptions of the Nusantaran archipelago ${ }^{8}$ has revealed that the plate was acquired in 1975 by the Rijksmuseum voor Volkenkunde (presently called Museum Volkenkunde) in Leiden, from a Mr. A.J. Dirks (of Den Haag), through the intervention of a Mrs. F. Groosbeek-Baretta (of Apeldoorn). ${ }^{9}$ The plate has the inventory number RV-4801-1 in the merged collection of the recently formed Nationaal Museum van Wereldculturen, measures $8.2 \times 41.5$ $\times 0.3 \mathrm{~cm}$, and bears five lines of writing on both sides. Good photographs of the plate ordered from the Museum make it possible to check and correct Brandes' reading on several points, and to propose a translation on the basis of the revised edition.

In the spirit of Boechari's words quoted above as motto, the first purpose of this article is to submit this inscription to a fresh study and to offer a translation into English. But my second purpose is to use this inscription to illustrate the significant progress that can be made more generally in the study of the epigraphic material of ancient Java - from the documentation of the physical whereabouts of inscribed artefacts, through the correct decipherment of the texts and the proper interpretation of the grammatical forms and lexical meanings of their words, to their exploitation for historical research.

\section{Text}

Using Brandes' edition as base text, I offer here a new edition of the inscription, following the transliteration conventions of the ERC-funded research project DHARMA, ${ }^{10}$ i.e., largely the ISO standard 15919 but with some adaptations, some of which now mean a break with the system that I have used in previous publications, ${ }^{11}$ notably the use of capital letters for akșara vowels that I would previously have indicated with a raised circle.

waren mij nog niet bekend." The information about Mr. Wiederhold is repeated in Rapporten van den Oudheidkundigen Dienst in Nederlandsch-Indië 1915: 185.

7. Damais (1955: 183): "Perdue ? Il n'existe ni photo ni estampage. [...] Rien ne semble subsister de cette inscription en dehors de la transcription Brandes. Nous sommes donc dans l'obligation de la reproduire sans changement." Without any apparent source, Nakada (1982: 106-107, entry no. 148) indicates "M[useum] of Malang?" - note the question mark.

8. See Perret, Machi Suhadi \& Richadiana Kartakusuma 2003-04. A first installment of the inventory will soon be published online through epigraphia.efeo.fr/nusantara/ idenk.

9. This information about the acquisition history is taken from the Museum's inventory card, which also indicates "ex collection Wiederholt" (sic).

10. See Balogh \& Griffiths 2019.

11. See especially Acri \& Griffiths 2014. 


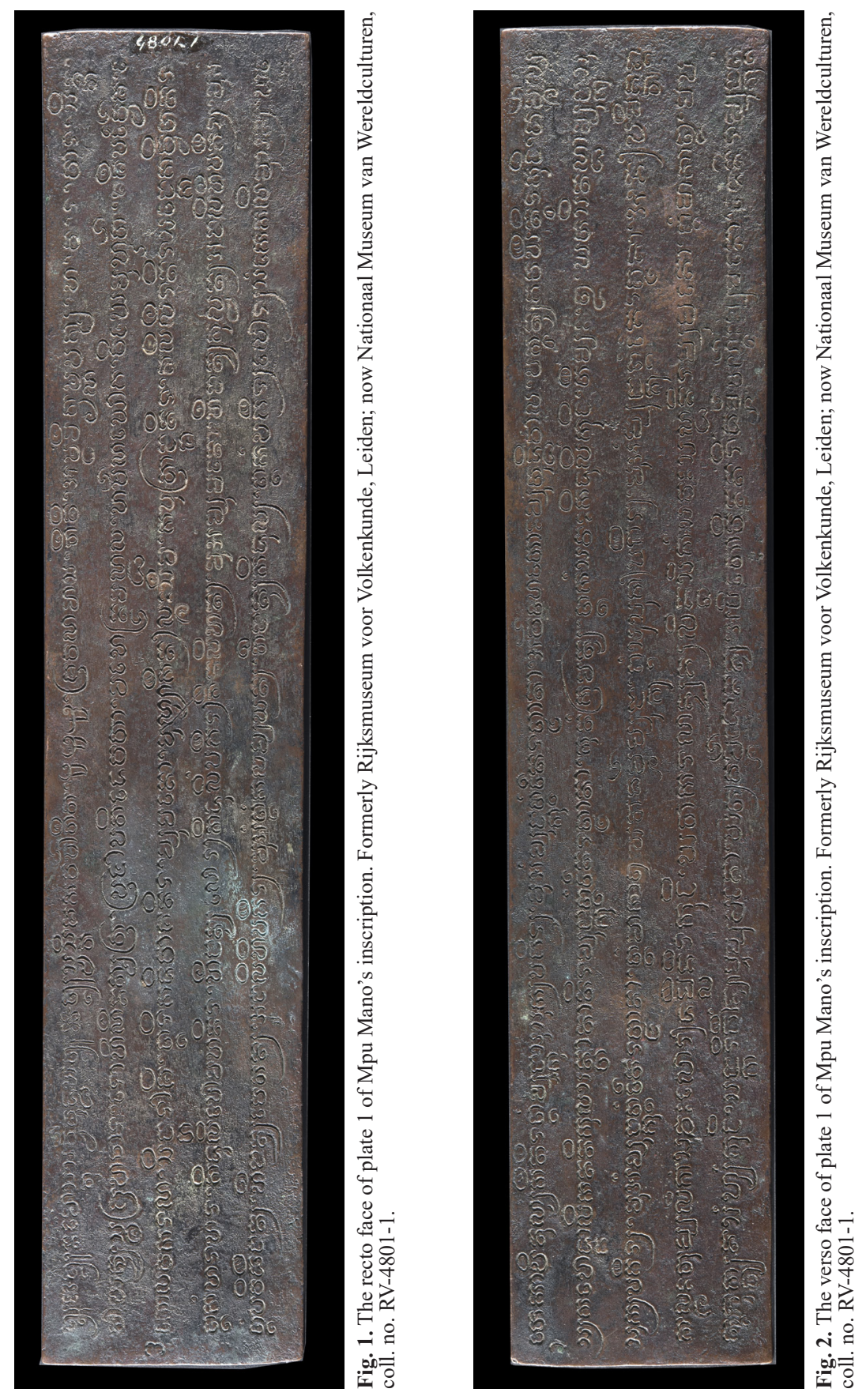




\section{1 recto (fig. $\mathbf{1})^{12}$}

(1) // 88 // namo stu sarvvabuddhăya // 88 // svasti śakavarṣātīta, 888, śrăvaṇamāsa, tīthīi, ${ }^{13}$ Așțamī krș̣napakșa, ${ }^{14}$ ha, va, ra, vāra, sinta, (2) bāyabyastha grahacāra, rohin̄inakșatra, prajāpatidevatā, mahendramaṇụala, harșaṇayoga, vijayamuhūrta,${ }^{15}$ śaśīparvvaiśa ${ }^{16}$ (3) kolavakaraṇa,${ }^{17}$ sinhharāśi, Irika divāśanira, mpu mano, munyākən lmạ̣ sīma, kaputrānśanira, kalilīranira ${ }^{18}$ sanke kavvitanira (4) Ikam $^{19}$ harahara, kidul i pomahanira, hīnanya lor· kidul im pagər· kinalihan', muAm mpu mano, hīnanya kulvan· Analih ${ }^{20}$ pagər', muAm (5) Im paviḍənan', hīnanya vetan', Analihi pagər', muAm Im kalampayan', hīnanya kidul', Ikam pagər· lor· samke kalimusan', ya t-

\section{1 verso (fig. 2)}

(1) ekân ${ }^{21}$ pinunyakənira Im mpunku susuk ${ }^{.22}$ pagər', muAm mpun்ku Im $^{23}$ nairañjanā, Arthahetoḥ mpu buddhivāla, paknanya gavayənnira kuṭi, dharmma lpa(2)s· kapodgālikanani kulasantānānira mpuñku Imm nairañjanā, kunam kramanya, Ikam savaḥ kidul im kuṭi, təmpaḥ, 3, ya ta sinaṇ̣̂ā mpuñku su(3) suk. ${ }^{24}$ pagər', muAm் mpun̉ku Im ${ }^{25}$ nairañjanā, Im mā kā 2(, $)^{26}$ ya ta dharmma mpuñku, ${ }^{27}$ Im susuk $\cdot$ pagər·, muAm mpun̉ku Im nairagjanā, ${ }^{28} \mathrm{An} \cdot$ paminta

12. The plate-number 1 stands in the left margin, rotated $90^{\circ}$ clockwise vis-à-vis the text.

13. tìthì: tithi Brandes.

14. krṣnapakṣa: śuklapakșa Brandes. Damais’ suspicion of an error in Brandes reading is thus confirmed. See below, $\S 4$.

15. - muhūrta: -muhürtta Brandes.

16. - parvvaiśa: -parvveśa Brandes.

17. kolava-: the taling stands at the end of line 2 but is repeated at the start of line 3 . See another occurrence of this (actually rather widespread) phenomenon indicated in n. 21.

18. kalilīranira: kaliliranira Brandes.

19. kavvitanira Ikam: kavvitanira, Ikam Brandes. No punctuation sign is engraved between these words.

20. Añalihì: Añalihi Brandes.

21. ya tekā: the taling stands at the end of line 5 of the recto, but is repeated at the start of line 1 of the verso. See also n. 17 above.

22. mpunku susuk $:$ since in most cases we find $I \dot{m}$ between these words, I assume that we must emend mpunkku Im susuk. here and in lines 2-3.

23. Im: I Brandes.

24. mpunkku susuk : see n. 22.

25. Im: I Brandes.

26. $k \bar{a}$ 2(,): the punctuation sign is very faint; it was not read by Brandes.

27. mpuiku,: the punctuation sign was not read by Brandes.

28. Im nairagjanā: I nairañjanā Brandes. Brandes did not observe that the plate here shows an error for the spelling of the toponym seen repeatedly in this text. Emend nairañjanā. 
I(4)ka lmạ̣ tumpal ika ${ }^{29}$ savaḥ lor· damlənira ${ }^{30}$ kuṭi, ya ta kăraṇanyan· linbas ${ }^{31}$ ikam savah saṇ̣anira mpu mano, Im mā kā 3, mapa(5)k(na) bhuktyana sam hyam kuți, sañka ri gə:mnnyāmbha mpu mano, ${ }^{32}$ yat ${ }^{33}$ dharmma donanya, Apitovin ana rim dharmma parnnah ${ }^{34}$ mpu mano, denira mpunku Im

\section{Translation}

(r. 1-3) Homage to every Buddha! Hail! Elapsed Śaka year 888, month of Srāvana, eighth tithi of the waning fortnight, Haryan, Vagai, Sunday, (the vuku) Sinta, the grahacāra in the Northwest, the lunar mansion Rohin̄i, the deity Prajāpati, the mandala in the East, the conjunction Harșana, the muhürta Vijaya, the regent of the astronomical node being the Moon, the half-tithi (karana) Kolava, the zodiac sign Leo.

(r. 3-5) That was the time that Mpu Mano made a meritorious donation of sima land that was his patrimony as child, ${ }^{35}$ his inheritance from his ancestors, the uncultivated field (hara-hara) ${ }^{36}$ south of where he resided. Its northern limit is south of the fence (pagrr) ${ }^{37}$ shared with Mpu Mano. Its western limit shares the fence with Pavidonan. ${ }^{38}$ Its eastern limit shares the fence with Kalampayan. ${ }^{39}$ Its southern limit is the fence north of Kalimusan. ${ }^{40}$

29. tumpal ika: tumpalikam Brandes. I think the cecak read by Brandes is actually just a scratch above the $k a$, although perhaps we do need a cecak here, if we are to understand tumpalnika( $\dot{n})$.

30. damlanira: damlira Brandes.

31. linbas: linbus Brandes. I do not see the needed suku. Emend tinbus.

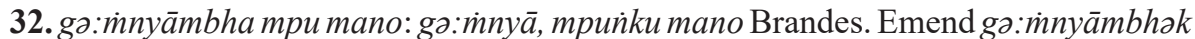
mри mano. The emendation is supported by analogous phraseology in several Parva texts, thought to date to roughly the same period as this inscription. See Addiparva, p. 97: sañka ri gànini prabhāvanira; Bhīṣmaparva, p. 84: sañka ri gänniñ krodha saǹ bhïmasena; Uttarakānda p. p. 126: saǹ hyan indra ta jugāgàn valasny ambəknira. On the spelling $b h$ in the word ambək, consistently found in the Majapahit-period manuscript of the Dharma Pätañjala, see Acri 2017: 55 / 2018: 40.

33. yat: emend yan' or yar.

34. parnnah: parnnah Brandes.

35. On the meaning of kaputräniśan, see $\S 6.1$.

36. On the meaning of hara-hara, see $\S 6.2$.

37. On the way I translate pagər, see $\$ 6.3$.

38. Zoetmulder (1982) records the word vidon in the meaning "(= yuyu) crab", but cites only one occurrence. If pavidərian is derived from that word in that meaning, it would have to mean 'crab farm', or such. But it seems imaginable that the word is

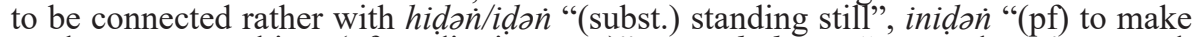
st. the constant object (of meditation, etc.)", mapahidzrian "to stand one's ground, recover, rally" (Zoetmulder 1982). The meaning of pavidanian could then be "place for solitary retreat (for meditation)' or 'rallying ground'. But it can also simply be a toponym, as I assume for the time being. The word does not occur elsewhere.

39. Or kalampayan could be a common noun connected with lampyay? kalampyayan ? "a part. kind of plant (creeper)?" (Zoetmulder 1982). The word does not occur elsewhere.

40. In origin, at least, kalimusan must be a common noun derived from limus "a 
(r. 5-v. 2) That is what he made a meritorious donation to the Master of Susuk Pagər and Master of Nairañjanā, [whose name mentioned here only] for practical necessity [is] ${ }^{41} \mathrm{Mpu}$ Buddhivāla, ${ }^{42}$ to serve for the monastery (kuti) to be made by him (Mpu Mano), a tax-exempt foundation (dharma lopas) that is to be individual property (kapodgalikan) ${ }^{43}$ of the lineage of the Master of Nairañjanā.

(v. 2-5) As for its details: the wet-rice field south of the monastery (kuti), [measuring] 3 tzmpah, had been taken in security by the Master of Susuk Pagər and Master of Nairañjanā for $2 k \bar{a} t ̦ i$ of gold. That (field) was the foundation of the Master of Susuk Pagər and Master of Nairañjanā, who (an) requested a border land, the wet-rice field to the north, (to be used) for his (Mpu Mano's) founding of a monastery. ${ }^{44}$ That is the reason why the wet-rice field given in security by Mpu Mano was redeemed by him for $3 k \bar{a} t i$ of gold, to serve for being used as resource by the Holy Monastery ( $k u t i)$, out of the greatness of the intent (ambok) of Mpu Mano that (yan) Dharma should be striven for by him. The more so as regarding the foundation (dharma), the relation of $\mathrm{Mpu}$ Mano to the Master of ...

\section{Date}

The inscription's date has been discussed in exemplary fashion by LouisCharles Damais (1955: 183). Unable to convert the date with the parameter śuklapaksa as read by Brandes, Damais had to assume an error with regard to the fortnight, because 888 Śrāvaṇa krṣnapakṣa 8 Haryan் Vagai Sunday yielded

part. kind of fruit (mango? cf sund.; GR: = timun)" (Zoetmulder 1982), i.e., 'limus orchard'. The word occurs as the name of a sima in an inscription which I suspect may be a reissue of a grant originally issued in the 11th century (Kalimusan, see Machi Suhadi \& Richadiana Kartakusuma 1996: 7). In its two occurrences in the Waringin Pitu inscription (ed. Boechari 1985-86: 125-136, lines 8r2, 11r3), it could be either toponym or common noun, although the former seems a bit more likely, because of the occurrence of the toponyms Malane and Kamalagen in the same contexts. An occurrence of the former in the Balawi inscription of 1305 Saka has been identified by Hadi Sidomulyo (2018: 237) with a village situated about $40 \mathrm{~km}$ northwest of Trowulan, but homonymic villages may of course have existed elsewhere; the latter is the name of a sima known from the Kamalagyan inscription of 959 Saka, which mentions it in close association with Varinin Sapta, none other than the sima which is the focus of the Waringin Pitu charter. (On that charter, see also §6.2.)

41. On the meaning of arthahetoh, see $\S 6.5$.

42. This name appears as Boddhivāla in the Sobhamerta inscription. It seems that a single person called Mpu Buddhibala (or something like that) was master of two establishments, one called Susuk Pagər and the other Nairañjanā, although the text does not consistently mention both affiliations.

43. On the meaning of kapodgalikan, see $\S 6.4$.

44. An alternative translation might be: 'That (field) was the endowment (dharma) for the Master of Susuk Pagər and Master of Nairañjanā, such that (an) he requested a border land, the wet-rice field to the north, (to be used) for his (Mpu Mano's) endowment of a monastery.' 
a perfect match with 12 August 966 CE. My new edition of the text confirms Damais' suspicion. In their review of Damais' data emphazing the traditional Indian pañcānga ('calendar with five elements'), which Damais generally ignored in his approach to date conversion based more on indigenous cyclical elements, Eade \& Gislén (2000: 68) confirmed Damais' result:

There is no kaulava karana on astronomical tithi 8 waxing, though there is one in the second half of 8 waning and Damais indicates (...) that a confusion between waxing and waning is "very easy to make". The diagram's figures for Kaulava (58' 2 I to 18'38) indicate that it, the nakșatra, and the yoga are all in place for just over half the civil day (...).

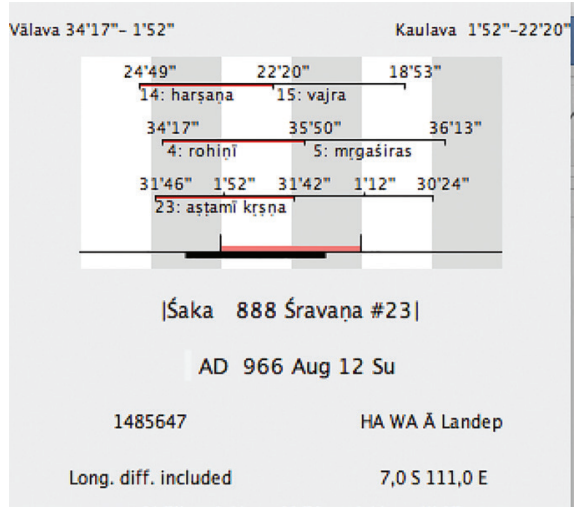

Fig. 3. Diagram showing the dating parameters of Mpu Mano's inscription.

To visualize what is explained here, see my fig. 3, a diagram which reproduces and enhances the one given by Eade \& Gislén. ${ }^{45}$ The only remaining incongruity is that the wuku is stated to be Sinta, whereas the combination Haryan Vagai Sunday should be the first day of Landəp as shown in the diagram and in Damais 1955, Appendix 1. On this unresolved issue, see Damais 1955, Appendix 9.

Damais also mentions that some parameters of the dating formula are incompatible with a date in 888 Saka, which indicated to him that he was dealing with a reissue in the Majapahit period. The idea, not made explicit here by Damais, is that the dating formula would have been expanded, without incidence on the critical parameters, to suit the customs of the Majapahit period by inserting parameters that were never included in earlier periods. The anachronistic parameters in our inscription may be brought out by juxtaposing its dating formula with a few others from inscriptions that are not reissues: ${ }^{46}$

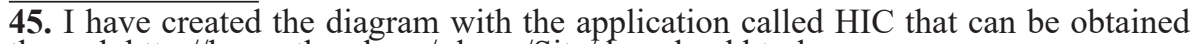
through http://home.thep.lu.se/ larsg/Site/download.html.

46. I quote the opening passages of the following inscriptions: (1) Hering, (2) Alasantan (ed. Wibowo 1979), (3) Muncang, (4) our inscription, (5) Cane. 
1. sakavārșatīta 859 jeșțamāsa tithi saști śuklapakșa ha va vṛ vāra agneyastha pūrbaphalgunanakșatra toyadevatā bajrayoga garadhikaraṇa

2. śakavarșātīta 861 bhadravādamāsa, tithi pañcamî krșṇapakșa, vā, pa, śu, vāra, aśvinīnakșatra, aśvīdevatā, vișkambhayoga

3. śakavarșāîtita 866 cetramâsa tithī șașți suklapakșa tu pa ā vāra, rohiṇinnakṣatra karșalaśadevatā, prītiyoga

4. śakavarșātīta, 888, śrăvanamāsa, tīthī, așțamī krṣnapakșa, ha, va, ra, vāra, sinta, bāyabyasthagrahacāra, rohin̄inakșatra, prajằnatidevatā, mahendramaṇdala, harșaṇayoga, vijayamuhūrta, śaśīparvvaiśa, kolavakarana, sin̄harāśi

5. sakavarșātîta 943 kārtikamāsa tithi caturthi krșnapakṣa tu va śu vāra landəp pūrṇnavasunakșatra śubhayoga ariditidevatā grahacārapūrvvastha vavakaraṇa bāyabyamaṇḍala

As Damais observes in a footnote, our inscription is "le seul document javanais retrouvé de la période s'étendant de la dernière charte de Pu Siṇ̣̂k à la grande stèle de 913 śaka dont le nom royal n'a pas encore été déchiffré", ${ }^{47}$ so that we cannot usefully compare the date of 888 Śaka with any date in the following decades until the Cane inscription of 943 Saka, which does show some new elements vis-à-vis the dates of 859,861 and 866 Śaka (grahacāra, mandala), but does not yet show any of the elements that become customary only later (muhūrta, parveśa, rāśi $){ }^{48}$

\section{Palaeography}

Both Brandes and Damais were undoubtedly right in arguing on the basis of the inscription's dating formula that they were dealing with a reissue. In Brandes' time, experience with Javanese palaeography was not sufficiently advanced for him to use any palaeographic argument, while Damais was unable to do so because he had access neither to the plate itself nor to any reproduction. Now that the documentary situation has changed, we can observe that the script is clearly different from what we see in original issues of the 10th century CE on stone and copper plate. The Alasantan inscription of 861 (fig. 4) may serve as example of the script typical in that period. On the other hand, the script we have seen in fig. $\mathbf{1}$ and $\mathbf{2}$ is entirely compatible with the hypothesis of reissue in the Majapahit period.

It seems that the hand that we see on our plate is particularly similar to, and therefore contemporary with, the one responsible for the engraving of

47. The published reading (OJO LVII) of the stele of 913 Saka is too fragmentary to use for comparison, and none of the dating formula is preserved in the case of the more recently discovered but still unpublished Wwahan (or Bandar Alim) inscription, except the Saka year 907. On this inscription and its date, see Boechari 1986: $190 \mathrm{n}$. 33 / 2012: 322 n. 31, Machi Suhadi \& Richadiana Kartakusuma 1996: 46 (photo on p. 71), and Boechari 2012: 184. I was able tentatively to confirm the extremely faint reading 907 at the top of the almost entirely effaced front face of this stone during a visit to Pusat Informasi Majapahit in 2015.

48. See De Casparis 1978, Appendix II ("Gradual lengthening of the expression of dates in Old-Javanese inscriptions"). 


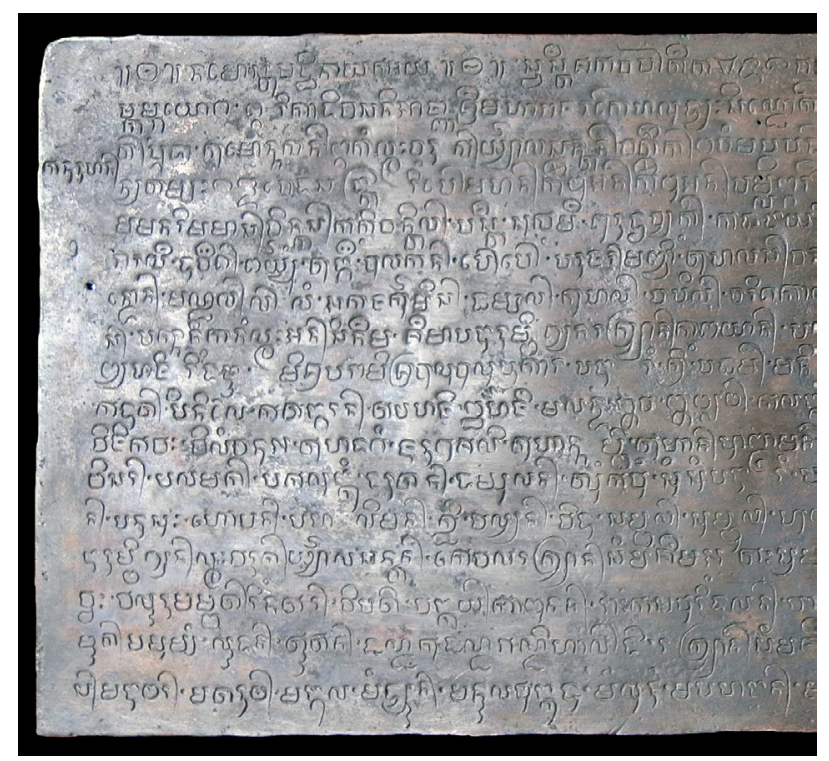

Fig. 4. Alasantan inscription, left half of text on plate 1. Pusat Informasi Majapahit, no. 5-8/Tbg/BJJ/63/BPG. Photo courtesy of Nigel Bullough.

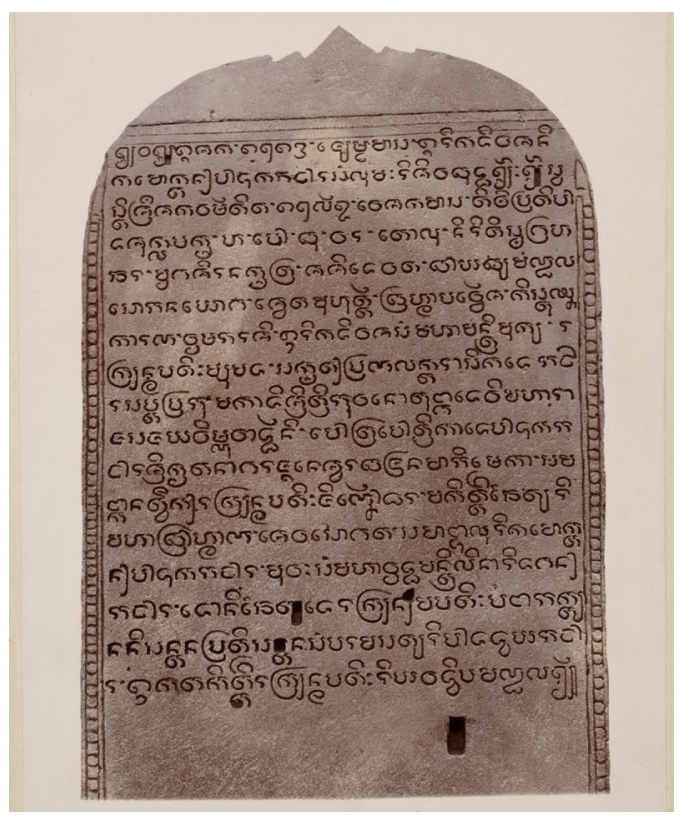

Fig. 5. Gajah Mada inscription. Museum Nasional, Jakarta, inv. no. D. 111. Photo OD OD-741A, courtesy of Leiden University Library. 


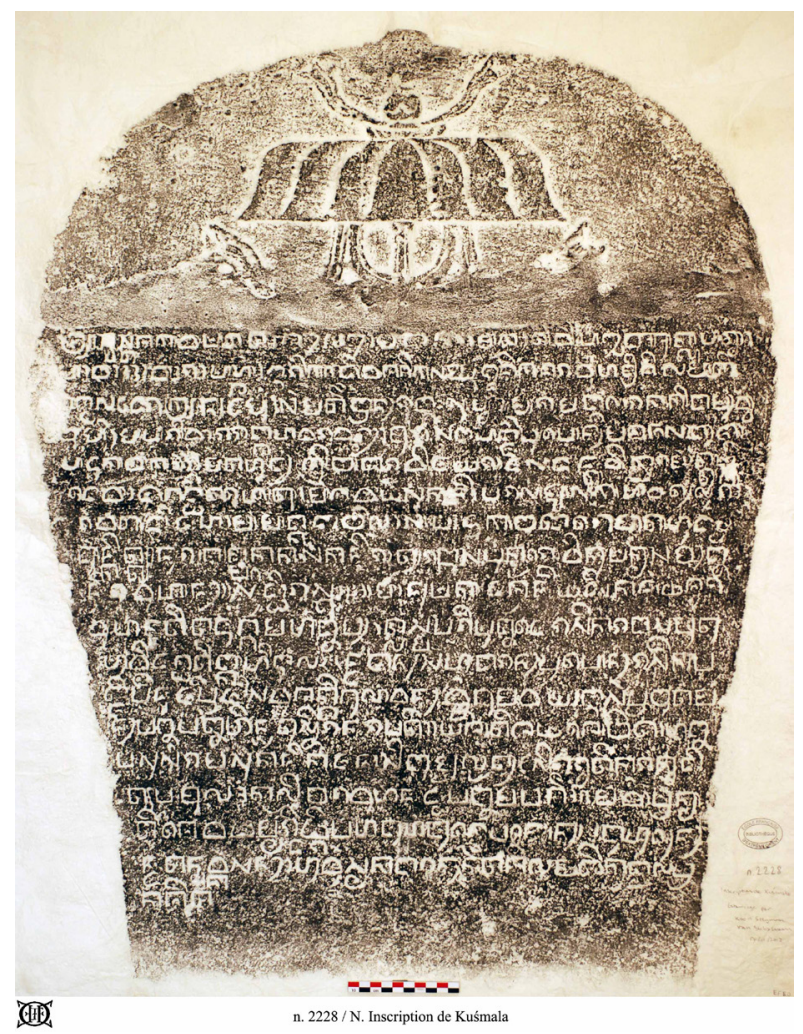

Fig. 6. Kusmala inscription. Museum Airlangga, Kediri. Estampage EFEO n. 2228. Photo courtesy of the EFEO.

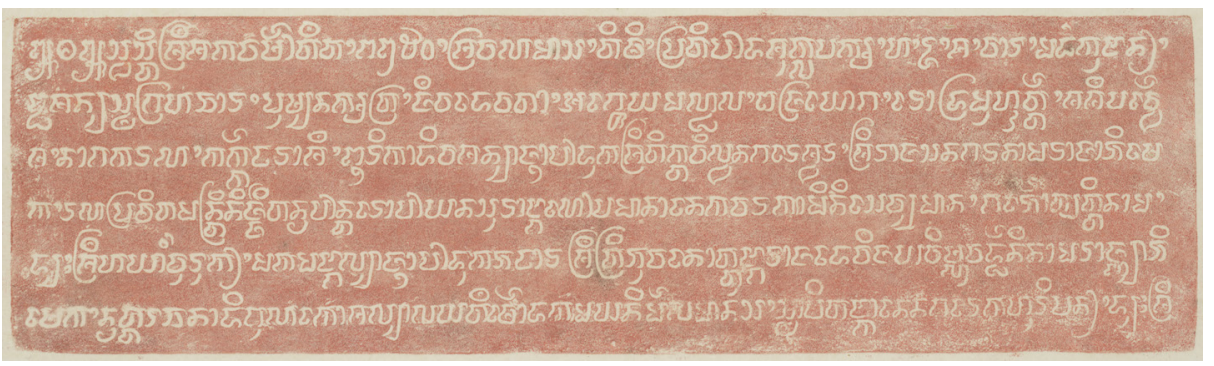

Fig. 7. Canggu inscription, plate 1 recto. Museum Nasional E. 54a. Rubbing kept at Leiden University Library. Photo courtesy of Leiden University Library. 
the famous Gajah Mada inscription (fig. 5), dated to 1273 Śaka, or 1351 $\mathrm{CE}$. The force of this comparison is brought out by showing another stone inscription of 1272 Śaka (fig. 6) and another copper plate of 1280 Śaka (fig. 7), both of which lack the peculiar roundedness that is common to our plate and the Gajah Mada stone inscription but that I have not found in any other inscription - giving reason to speculate that the same engraver may have been responsible for both. And it is further noteworthy that the script used to reissue Mpu Mano's grant is quite different from that used in the reissue of the textually related Sobhamerta charter. ${ }^{49}$ The two grants were probably not reissued during the same century.

\section{Vocabulary}

\section{1 kaputrāñśan}

After the dating formula, the object of the grant is described in the following words: irika divāśanira, mpu mano, munyākon lmah sīma, kaputrāñśanira, kalilìranira sankke kavvitanira, ikan hara-hara, kidul i pomahanira, hïnanya lor kidul in pagər kinalihan, muan mpu mano. While the words hara-hara and pagar will be discussed in $\S 6.2$ and $\S 6.3$, we shall first concentrate on kaputräñśan. In the Old Javanese-English Dictionary (Zoetmulder 1982, henceforward $O J E D$ ), we find the following entries:

putrāñśa, kaputrāñśa, kaputrāñśan

putrawañśa $=$ putrāñśa

kaputrawańśa, kaputrawańśan apanage, land assigned to a son by the king.

With the exception of two references to the Navaruci, all of the textual passages cited by Zoetmulder are epigraphic. When checked against the most reliable editions available, it appears that none of the occurrences actually requires postulation of a form kaputrāniśa or kaputravaniśa, without -an suffix.

Including the one in our inscription, we can list the following epigraphic occurrences (cited here in somewhat normalized transcription):

1. Waharu I, reissue of a grant dated 795 Śaka, lines 1r3-4: parnnahanya sìma kaputrañśana, kalilirana denin anak putu buyut santāna pratisantāna sañ hadyan ${ }^{50}$

49. See Damais (1955: 60 n. 1): “Ainsi qu'on peut le voir dans le fac-similé de $K \dot{O}$, XXII, l'écriture de cette copie diffère nettement de la plupart des autres copies tardives. Elle leur est probablement antérieure, mais nous n'osons préciser plus pour le moment." See already Damais 1952: 60-61, n. 6. Five of the inscription's seven plates are kept at the British Library, and can be viewed through that institution's online database: http://www.bl.uk/manuscripts/FullDisplay.aspx?ref=MSS_Jav_106.

50. Ed. Boechari 1985-86: 22-25. 
2. Pupus, a reissue, possibly in the same hand as that of Waharu I (no. 1), ${ }^{51}$ of an original grant possibly dated to around 800 Śaka, lines 1v2-3: tatkālanikan van[v]a ri pupus vatək vatu humalan sinima de rahyañta sañjaya lbak vukirnyadohnyaparo lmah kabvanya tka ri kalan kalagyanya paniurumbiginya sima kaputraíśan de rahyanta sañjaya. Same inscription, lines 2r5-6: saman்kana lvāni lmah san் hyan் sìma i pupus kaputrańśan rahyañta sañjaya ${ }^{52}$

3. Paradah II, 865 Śaka, front face, lines 9-11: putraìśs ${ }^{53}$ kaliliraṇa denin anak putu puyut mani antah santāna pratisantāna sañ śluk dāyanya rikana sa san் maputra tinkahnikanan $\dot{n}^{54}$ lmah savah sima pacaru $i$ san hyan் dharmma kamūlān blah 1 panajyan su ku 1 (?) a .... ka 1 putràiśa tampah 1 ... ikanan் lmah gagā ... i tagin tampah blah putrañśa juga man்uñsi i pinhai panigaran i paradah. Same inscription, back face, lines 28-29: asin umulahulah ikan

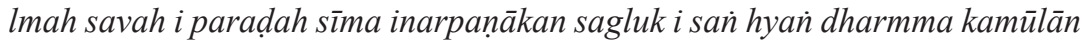
i paradah lornin luah muan ... i tagin putraniśa in dlāha hlam an babatataya nunivaih yan davuta san் hyan் vatu sìma kabuattananya patyananta ya

4. Kancana, a reissue dated to 1295 Śaka of a grant originally issued in the 10th century $\mathrm{CE},{ }^{55} 4 \mathrm{v} 4-5 \mathrm{r} 3$ : samañkana pañaturdeśani lmah san் hyan் darmmasima ìn kăñcana, kavibhajyanikan் savah, maprayoga i bhațāra, təmpah, 2, in asana

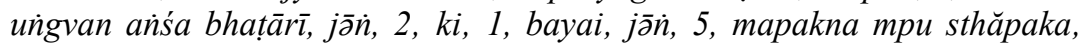
tompah, 2, in gayanti unggvanya, mpu brahmā ta sthāpaka, mpu asthavira, ${ }^{56}$

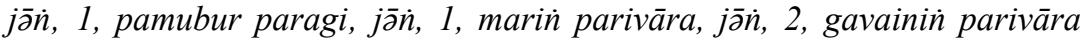
kinonkon adoh aparək hōbnin bapra, jān், 2, kaputrān்śan, təmpah, 20 dyah imbañi, mvà் dyah anārgha pramāna ikā, tka i santāna pratisantānānikā, tka mne hlom rin dlāhanin dlāha

\begin{abstract}
51. On the Pupus inscription, see Damais (1952: 11 n. 2): "L'inscription de Pupus (OJO, $\mathrm{LXV}$ ) forme un cas à part. Elle a une date complète (c'est à tort que la transcription de Brandes ne donne que quelques mots des lignes 1 et 2 car elles sont presque entièrement lisibles). Le style rappelle nettement les inscriptions de la fin du VIII ${ }^{\mathrm{e}}$ et du début du $\mathrm{IX}^{\mathrm{e}}$ siècles Saka. Comme cependant le nom du wuku s'y trouve indiqué, on pense à une date postérieure. L'écriture, anguleuse, est difficilement datable. Le millésime ne saurait en tout cas être 1022 Saka et Stutterheim a certainement eu tort de partir de cette date pour l'article qu'il a consacré à ce document $(B K I, 90,1933,282-287)$. Nous n'avons pu jusqu'ici trouver de solution satisfaisante pour l'interprétation de la date et nous en reparlerons ailleurs." Note the similarity of the words used by Damais (1955: 31) when discussing Waharu I: “il s'agit d'une copie, mais non d'une copie tardive car l'écriture est nettement antérieure à la période de Majapahit. Anguleuse, elle est difficilement datable et il s'agit peut-être de ce que nous avons appelé une " copie conforme »." My suggestion that the two copies were made by the same hand is based on inspection of rubbings of the plates (Museum Nasional E. 3 and E. 24) kept in the Kern Institute collection of Leiden University Library.
\end{abstract}

52. Ed. Boechari 1985-86: 75-77.

53. Emended. Brandes reads patlainśa, with indication of uncertainty.

54. Emended. Brandes reads titah nikanan.

55. On this dating, see $\S 7$.

56. Emended. The plate reads hasthavira. 
5. The present inscription: munyākan lmah sìma, kaputrāṅśanira, kalilīranira sañke kavvitanira, ikan் harahara

6. Pabuharan, a reissue of a grant originally issued possibly under the reign of Siṇ̣ok or Airlangga, lines 1b2-4: ika ta makadrabya ikan kaputravaniśan, lukat tampah, 1, muan kamüladharmman, lukat, ki, 1, makamukhya savah bhațāra kabhaktin, an lukat, jon, $1^{57}$

7. Waharu III, a reissue of a grant originally issued possibly under the reign of Siṇ̣ok or Airlanga, line 3r3: atəhər inanugrahan kaputravańśan savah ${ }^{58}$

8. Wimalasrama, reissue of a grant originally issued possibly under the reign of Siṇ̣ok or Airlangga, Hageman transcript, page 3, lines 2-3: damlan kaputrańśan satnah paniklana susur kapangiha kalilirani vka vetnira mpunkku muntun $^{59}$

9. Rameswarapura, 1197 Śaka, lines 6r4-6: ya teka parnah kaputrāìńanani santāna pratisantāna śrī brahmarāja, mvañ ikan் ulihnin் amabaki, kuñ̄ं ikan் gagā, kubvan, parṇah kaputrāíśan $i k a^{60}$

10. Sukhamerta, 1218 Śaka, line 11r3: hana pvekāin savah kaputrāinśan, irika ta sañ apañji patipati yan tan ārthakāraṇa

Besides these epigraphic occurrences, predominantly dating from the 10th and 11 th centuries, in the transmitted Old Javanese literature there are the two passages from the Navaruci cited in OJED, and a further passage not cited there:

11. Navaruci, chapter 2, first paragraph (pp. 29-30): kañcit man்kat rahaden bhīma. kapun்kur in gajāhoya. tan kavarnaa tikan் kalagen, kaputravańśan, muvah tikan் kaperin் mvan் kalintanan. 'Immediately Bhīma set out. He had left Gajāhoya behind. The religious establishments (kalagen) and kaputravaniśan will not be described, nor will (the places) he passed by and came across.' Same text, chapter 3, first paragraph (p. 34): aglis man்kat rahaden bhïma, kapun்kur

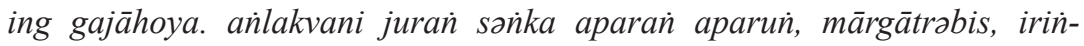
irin. akveh tikan் vanādri bhaya kalintañan, muvah śəma, vatəs, pabajañan,

57. Ed. Boechari 1985-86: 13-14. Despite what is suggested by inclusion in Boechari's work, it is unclear to me whether the original plates forming this inscription have ever been actually kept at Museum Nasional. What is certain, is that the British Library now preserves the plates under shelf mark Ind. Ch. 57. Photos are accessible online, enabling me to check published readings of the lines in question: http://www.bl.uk/ manuscripts/FullDisplay.aspx?ref=Ind_Ch_57\&index $=13$.

58. Boechari 1985-86: 89-92.

59. Van Stein Callenfels 1924: 25-26; reading corrected on the basis of my inspection of the manuscript kept at the Bibliothèque nationale in Paris, and further emended.

60. No edition of this charter has been formally published, although there is a reading in an unpublished "Laporan penelitian prasasti di Museum Mpu Tantular dan di Museum Purbakala Trowulan tahun 2003" by Machi Suhadi. I quote from my own forthcoming edition. 
pen்ənan ìn avan; gunun் pipitu kalintanan; mvan் kapun்kur tekang taruktarukan, muvah kalagen, kaputravañśan, dusun, kuluvutan. 'Immediately Bhīma set out. He had left Gajāhoya behind. He marched through steep ravines with rocks and cliffs. The path was rocky terrain and slopes. On the road, he came by numerous dangerous forest mountains, cemeteries, boundary markers, children's graveyards, demarcations. He came by seven mountains. And he left behind settlements, as well as religious establishments (kalagen), kaputravaniśan, and remote villages.'

12. Rājapatiguṇala, transcribed by Pigeaud (1960-63, vol. I: 88-89) from

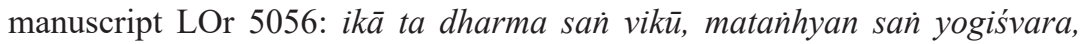

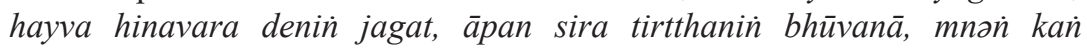
pramananin rāt, kāryyanira n்ukușakən dupā, rin śüklapakṣa, makañūni

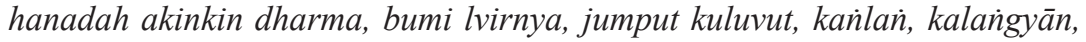
kaputravaíśān, tani, hanālaga dalun, salviranin bhümi carik, Imah ahen, tan salah amūktyakna. In this passage, kalaingyān must correspond to the kalagen of the Navaruci passages.

Clearly, the data reveal that the original and older spelling is $(k a) p u t r a \bar{n} \dot{s} a(n)$, i.e., from Sanskrit putra+aíśa. Prijohoetomo explains in his glossary (1934:

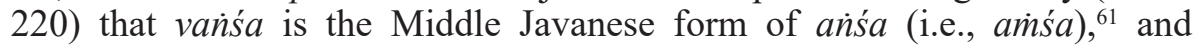
translates kaputravaniśan as "inherited land" (erfland). This was also the interpretation given by H. Kern and after him by H.B. Sarkar for the occurrence in the Kancana inscription (no. 4), where the former translated "erfdeel" and the latter "patrimony for the children". ${ }^{2}$ The occurrences listed above do not give clear support for Zoetmulder's more specific interpretation as "apanage, land assigned to a son by the king", because there is only one case of direct involvement of the king (in no. 2). But the idea that the word designates some kind of land is confirmed by its regular collocation with the words sima (nos $1,2,3,4,5)$ and savah $(3,4,6,7,10)$, while Prijohoetomo's idea that we are dealing with inherited land is supported by collocation with such phrases as kalilirana denin anak putu buyut santāna pratisantāna (1, see also 3 and 5), which can be read as glosses of putrāinśa.

In his glossary, Sarkar 1971-72, vol. II: 355 cites "sanskrit Putrāñśa, patrimony of the children" suggesting that it is a common Sanskrit term. It is remarkable, however, that this word, despite being entirely transparent as a Sanskrit compound meaning 'son's (or sons') share', does not seem to occur in Indian Sanskrit sources. It is therefore likely to be a compound of Javanese vintage. But I see no reason not to accept the translation proposed by Sarkar in

61. This claim is not confirmed by the entry waniśa in OJED (a dictionary which, despite its title, also covers Middle Javanese). Another way to interpret the form putra-v-añśa might be to consider the extraneous consonant to serve as hiatus-bridger allowing to avoid vowel sandhi in putra+amía.

62. See Kern 1917a: 23; Sarkar 1971-72, vol. I: 147 and vol. II: 355. 
favor of the more specific one indicated in the OJED. The $k a-\ldots$-an circumfix found in most occurrences can then be interpreted as expressing the status of the lands as putränśa.$^{63}$

\section{2 hara-hara}

Ever since Louis-Charles Damais introduced a new nomenclature for Indonesian inscriptions taking text-internal toponyms as basis, ${ }^{64}$ and listed this inscription under the designation "Hara-Hara", almost all scholars have adopted this designation which implies that the word hara-hara is a toponym, an implication which is sometimes presented as fact. ${ }^{65}$ Although she does not state this explicitly, Jan Wisseman Christie (2009: 46, 180) must have considered that such is not the case, because she chooses a different designation, "Mpu Mano inscription". I recommend adoption of this new designation, because hara-hara is more likely to be a common noun than any kind of toponym. Indeed, Kern (1911: 199) translates the term as "woeste gronden" and the $O J E D$ has an entry hara-hara, ara-ara "treeless and uncultivated field or plain". The dictionary cites only non-epigraphic occurrences, among them two telling stanzas from the Deśavarnana (which I quote in normalized transcription, along with Robson's 1995 translation):

sampun prāpte kulur mvañ batan i gañan asəm teki lampah narendra, tis-tis hyañ sūrya pintən ghatita pitu sirəm kāmukan sañhub avrā, skandhāvāre tən்ahnin hara-hara dinunuñ śrī narendre kamantyan, prāptañ vyāpāra sampun panaḍahira madum sthāna tekiñ vvañ akveh (18.8)

'Having reached Kulur and Batang, the King now went on to Ganan Asəm; the holy sun grew cooler and at about the seventh hour $(4.30$ p.m.) was dimmed, veiled by a spreading mist. At a camp in the midst of a grassy field the King was presently lodged. Refreshments arrived and after he had eaten we ordinary people each went to our own abode.'

śīghrān detən் i pajarakan patan dina lavas narapatin aməgil, ṅkānen̉ hara-hara kidul iǹ sudharma sugatāsana makuvu-kuvu, mantrī viku haji karuhun sañ ārya sujanottama parən் umarək, kapvānaturakən upabhoga bhojana vineh dhana paḍākasukhan (32.1)

'The King soon arrived in Pajarakan where he stayed for four days; the grassy field to the south of the Buddhist foundation was where they set up camp. The officials and King's priests led by the excellent Ârya Sujana came forward to pay their respects. And having offered him refreshments and food they were given money, which pleased them.'

63. See Zoetmulder 1950: 74 (no. 2); Zoetmulder \& Poedjawijatna 1992, vol. I: 88-89 (no. 2).

64. Damais 1952: 7-9 (§18-25).

65. See, e.g., Sejarah Nasional Indonesia, vol. II, p. 196, speaking of a "tanah sìma ... yang terletak di Desa Hara-Hara" (Bambang Sumadio \& Endang Sri Hardiati, eds., 2008). 
The OJED cites no epigraphic occurrences for the word, but besides the one in our inscription, at least one more is known to me:

Waringin Pitu, 1369 Śaka, 10v1-3:66

muva hana hara-hara kagarbbha rim bəron ·, pañrt vetan·, dpa, 83, pañlari kidul , dpa, 202, pan̈rt kulon', panlari lor., paḍa lavan vetan kidul · // muva hanālas kabhukti sakim sam hyam ḍarmma rim varinin pitu, rim pūrvvāsiḍakətan lavan niru, ...

'And there is a hara-hara falling under Boron: (its) eastern barrier 83 fathoms, (its) southern length (? panilari) 202 fathoms, its western barrier (and) northern length equal to the western and southern ones. And there is a forest used as resource from the holy foundation of Varinin Pitu, at its eastern points it adjoins Niru ...'

Here, the parallelism between muva(h) hana harahara and muva(h) hana alas clearly demonstrates that hara-hara must be common noun and not a toponym. ${ }^{67}$

\section{3 pagar}

The problem of whether a given word is to be interpreted as a toponym or as a common noun is indeed confronted very frequently when dealing with Old Javanese inscriptions, the data often being insufficient to make a reasoned choice. Some minor cases have been briefly discussed above in footnotes 38 , 39 and 40. I turn here to the more important case of pagar.

Hadi Sidomulyo (2010: 22, n. 67), in discussing royal foundations in the ancient region of Jangala (corresponding to modern Sidoarjo regency), took this pagar to be a toponym: "It can be added that the name Pagerr is recorded in a number of very early inscriptions originating from this same region, among them Kaladi (909) and Hara-hara (966)". In an earlier work, the same author has discussed the toponym at greater length, and referred to the mention made in the Mula-Malurung and Sukhamerta inscriptions, dated respectively to 1177 and 1218 Śaka, of a foundation (dharma) at Pagər. ${ }^{68}$ There is even a passage, among the inscriptions of that period, where the word undeniably serves as toponym in the determination of land boundaries:

66. Edited by Boechari 1985-86: 125-136. Reverified against my photos of the original.

67. I have found one other possible occurrence, the second set of Ukir Negara plates, a reissue of a grant originally issued in 1120 Saka, $1 \mathrm{v} 4-5$, where I read from photos of the plate: kulvan i humah dagal, 5 jum ludum, 2 jum, a(k)ulu (h)ara-hara drvya haji ma 1. I am unable to determine the meaning here, because I do not understand the word akulu, if that reading is correct. Machi Suhadi \& Richadiana Kartakusuma 1996: 9 read ahulu, which I cannot interpret either. Nigel Bullough (pers. comm.) kindly informs me that Issatriadi (1975: 18, 22 - unavailable to me), who likewise reads ahulu hara-hara, translates this as "di hulu padang". The reading ahulu is perhaps possible, but it seems impossible to me to translate ahulu as 'di hulu'.

68. Hadi Sidomulyo 2007: 83-84, with note 187 on page 108. 
Rameswarapura, 1197 Śaka, 6v5-6: ${ }^{69}$

Asidaktan lavan · blut·, manalor amgat lvah, dpa 340, Asidaktan lavan· pagə:r·, mlut· manetan analor·, dpa 80, Asiḍaktan· lavan· soso, manalor amnə:r·, tkem paścima, dpa 110

Adjoining with Blut, it goes North cutting through the river, for 340 fathoms. Adjoining with Pagər, windingly (?) it goes North-East, for 80 fathoms. Adjoining with Soso, it goes straight North, and arrives at the West point, for 110 fathoms.'

But if we assume pagar is a toponym also in the context of the land demarcation in our inscription, the resulting translation would have to be something like this: 'That was the time that Mpu Mano made a meritorious donation of sima land [...]. Its northern limit is the south (side) of Pager that is shared with Mpu Mano. Its western limit shares Pagər with Paviḍnnan. Its eastern limit shares Pagər with Kalampayan. Its southern limit is Pagər north of Kalimusan.' This seems to make less sense than if we translate pagar as a common noun meaning 'fence'. By contrast, I assume that it is part of a toponym in the combination Susuk Pagər. For the time being, within the limits of my knowledge and the sources available to me, I am unable to propose identifications of any of these toponyms on the modern map. ${ }^{70}$

\section{4 kapodgalikan}

The purpose of the transaction recorded in the inscription is stated in the words paknanya gavayənnira kuți, dharmma lpas kapodgālikanani kulasantānānira mpuìku in nairanjanā, which I have translated 'to serve for the monastery (kuti) to be made by him: the tax-exempt foundation (dharma) that is to be individual property (kapodgalikan) of the lineage of the Master of Nairañjanā.'

The word kuti is used quite commonly in Buddhist sources from ancient Indonesia to designate some kind of Buddhist establishment, probably monastic, not clearly distinguishable from and often appearing in collocation with the more familiar term vihära. ${ }^{71}$ Indeed, in the Sobhamerta inscription, the object of donation to the same protagonist - the Master of Nairāñjanā called Boddhivāla or Buddhivāla - as the one who figures in the inscription that concerns us here, is called vihanton, ${ }^{72}$ a krama-like derivation from the Sanskrit word vihära. ${ }^{73}$ In Old Javanese sources, the word vihära is a

69. See n. 60 above. I quote from my own forthcoming edition and translation.

70. In his article dedicated to toponyms in several Old Javanese inscriptions, van Stein Callenfels (1929: 382) also admitted his inability to identify any of these items. Nigel Bullough (pers. comm.) suggests to me that it is most likely that the toponyms are to be sought in the area between Surabaya and Trowulan.

71. See Griffiths 2014: 216.

72. Ed. Titi Surti Nastiti 2007, lines 2v3, 3v2, 3v5, 4v2.

73. The same form is also found in the Hering inscription that I will cite below. On 
sure marker of a connection with Buddhism. While the word is found in all literary and didactic texts preserved to us that have explicitly Buddhist preoccupations, it is, to my knowledge, hardly ever attested in such texts which have other religious affiliations. ${ }^{74}$ In epigraphic texts, the context is often insufficient in itself to determine with certainty whether a monastery of Buddhist or some other affiliation is intended, but in all cases where the context does throw light on the matter, it is clear that vihära designated specifically Buddhist establishments. ${ }^{75}$ Even if we forget the fact that the Mpu Mano and Sobhamerta inscriptions open with brief Sanskrit expressions of homage to all Buddhas, ${ }^{76}$ these other reasons alone would suffice to remove any doubt that we are dealing in both inscriptions with a transaction involving a Buddhist beneficiary.

In this light, it is remarkable that the OJED contains the following two entries for words quoted from the same two inscriptions, Mpu Mano and Sobhamerta, but occurring nowhere else in transmitted or epigraphic Old Javanese texts known to me:

podgalika Śiwaite

CSt 22 (939) 1b.4: muan் tan panjjurwa kaliliran i kula santāna mpuñku těka rin dlāha nin dlā $<$ ha $>$, parnahanya podgalika.

kapodgalikan establishment of Siwaites, Siwaite sanctuary

OJO 55 (966) b2: gawayěn ira kuți, dharma lěpas kapodgalikana ni kulasantāna nira mpunkku in̉ Nairañjana.

Now the base word podgalika, in the standard Sanskrit spelling paudgalika, ${ }^{77}$ is a well-known technical term of Buddhist monastic discipline (vinaya), ${ }^{78}$ and

such krama-like formations in Old Javanese, see Damais 1950, Damais 1951: 12 n. 1 and Hoogervorst 2017, table 3. Several examples can be added from epigraphy, among them the toponym a lasantan, in the eponymous inscription of 861 Saka, which is the equivalent of the common modern toponym Wonosari (i.e., vanasāri, meaning Flower Forest), although in modern Javanese alas is the ngoko-form while wana is the krama-form. Damais (1950: 269, 276) has emphasized the importance of kramaforms of modern toponyms, and a significant percentage of the krama-like forms found in Old Javanese are indeed toponyms or, like vihantzn, words that designate respected places.

74. See, by way of example, the occurrences in manuscripts of the prose recensions of the Kuñjarakarna story (van der Molen 1983: 136-137); in the kakavin Kuñjarakarna Dharmakathana $(1.7,6.8-9,11.4,15.9,16.2,32.6)$; in the Advayasādhana part of the so-called Saì Hyan Kamahāyanikan (Lokesh Chandra 1997: 343); and in the Deśavarnana (93.1, in this text the word kuti is far more common). Exceptions, always in rather stereotypical lists of various religious establishments: kakavin Rāmāyana (3.70); Agastyaparva (27.22-29 and 69.8-16).

75. The most noteworthy example is the Wanua Tengah III inscription (Boechari 2012: 484-491).

76. The invocation reads namo stu sarvvabuddhāya in Sobhamerta.

77. Representation of the Sanskrit diphthong $a u$ as $o$ in Old Javanese is normal: see Gonda 1973: 369-370 ( $1^{\text {st }}$ ed. 239-240).

78. See, for instance, Schopen 2001: 111-112. 
the corresponding entry in Edgerton's Buddhist Hybrid Sanskrit Dictionary (1951) reads as follows:

paudgalika, adj. (Pali puggalika; to pudgala plus ika; in different sense recorded pw 4.302), individual, personal, always contrasted with sāmghika, sometimes also staupika: sāmghikāh puṣpavṛkșāḥ... ${ }^{\circ}$ ka-paribhogena bhuktăh Divy $342.19, \ldots$ were put to individual, personal (not selfish, with Index) use; staupikam sāṃghikaṃ... vittam ${ }^{\circ}$ kam ca RP 29.8; similarly Sikṣ 63.14; Bbh 166.26; MSV ii.123.19.

Zoetmulder's interpretation of Old Javanese podgalika was clearly determined by the meanings ascribed to the word pudgala and podgala in his dictionary: "(Skt pudgala, a name of Śiwa) Śiwaite, follower of the Śiwaite way". ${ }^{79}$ Although Edgerton's dictionary is among the sources consulted by Zoetmulder when he was preparing the OJED ${ }^{80}$ his entry for podgalika reveals that he failed to observe the clearly Buddhist context of the quoted phrases, and forgot to consult Edgerton's dictionary. In brief, when a second edition of the OJED is prepared, the meaning for the entry podgalika and its derived form kapodgalikan will need to be corrected.

In that perspective, it must be noted that while paudgalika is an adjective in Sanskrit, the identification of the word class of Sanskrit words borrowed into Old Javanese is often problematic ${ }^{81}$ so that we may either consider the word podgalika to have remained an adjective in Old Javanese, with the meaning: 'belonging to (a Buddhist monk's) individual property', or to have been borrowed as a substantivized noun meaning '(a Buddhist monk's) individual property ${ }^{82}$ The function of the circumfix $k a-\ldots$-an in the derived form is in any case certainly not to indicate an establishment or sanctuary (as Zoetmulder presumed), but would either be to resolve the ambiguity of its word class, to create an abstract noun, or to indicate a status as in the case of kaputrāinśan discussed above. ${ }^{83}$

\section{5 arthahetoh}

The beneficiary of Mpu Mano's donation is identified as follows: ya

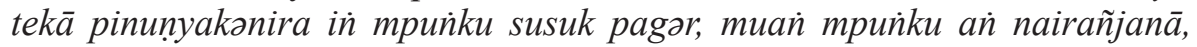
arthahetoh mpu buddhivāla. Above, I have proposed the following translation: 'That is what he made a meritorious donation to the Master of Susuk Pagər

79. Gonda 1973: $275\left(1^{\text {st }}\right.$ ed. 172).

80. See Zoetmulder 1982, vol. I: XXIII.

81. Gonda 1973: 582-584 ( $1^{\text {st }}$ ed. 388-390).

82. The latter might be deemed to follow from the juxtaposition of the phrase parnnahānya podgālika in Sobhamerta with such phrases as parnnahnya simma svatantrā (Turun Hyang) and kevalā sìmā svatantra juga parṇnahnya (Garaman, Boechari 2012: 503-512).

83. Cf. p. 122. See Zoetmulder 1950: 73-75 (nos 1, 2, 4); Zoetmulder \& Poedjawijatna 1992, vol. I: 87-90 (nos 1, 2, 4). 
and Master of Nairañjanā, [whose name mentioned here only] for practical necessity [is] Mpu Buddhivāla.'

The word arthahetoh, obviously of Sanskrit origin, occurs in a limited number of Old Javanese inscriptions all dating to the 10th century CE:

1. Wurudu Kidul, 844 Śaka, verso, 1. 19: likhita tambra arthahetoh dan ācāryya i grih prāmodyajāta ${ }^{84}$

2. Kanuruhan, 856 Śaka, 1. 6: irikā divaśa rakryān kanuruhan arthahetoh dyah mumpan் umanugraha ${ }^{85}$

3. Hering, 859 Śaka, face A, 1. 23: i sira arthahetoh sam prasantamatih

4. Sobhamerta, 861 Śaka, seven occurrences (1r4-5, 1r6, 1v2, 1v6, 2r1-2, $2 \mathrm{v} 33 \mathrm{v} 2$ ), always in the same sequence mpuñku $i$ nerāñjanā, arthahetoh boddhivala $^{86}$

If we include the occurrence in the Mpu Mano inscription itself, this amounts to five epigraphic sources, all but one of which (no. 2) were cited in the OJED entry arthahetoh which is furnished with the gloss 'for the benefit of?'. No non-epigraphic occurrences are cited in this dictionary, but I have identified one and will return to it below.

In all cases, the word stands between the designation of a respected person and his name. The gloss proposed with a question mark by Zoetmulder does not fit in the contexts. And indeed other scholars have proposed different interpretations. Let me first quote from unpublished notes on the Kanuruhan inscription (above, no. 2) by J.G. de Casparis: ${ }^{87}$

Finally, there is a minor problem concerning the term arthahetoh in 1. 6. This is a correct Sanskrit compound meaning 'on account of (for the sake of) a purpose (material gain etc.)', but in Old Javanese inscriptions this term is generally used between the title and the name of a person, as in the present case between rakryān kanuruhan and pu mumpang, where this Sanskrit meaning does not make good sense. It is, in fact, an apposition to the title rakryān kanuruhan. Also the translation in the dictionary of Zoetmulder-Robson, s.v. arthahetoh, viz. 'for the benefit of?' is unsatisfactory. Stutterheim 1925: 59 f., notes a similar use of the

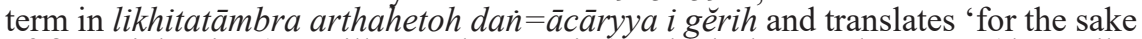
of financial gain' ('terwille van het gewin'), which does make sense (the scribe who writes the edict for a certain fee), but is grammatically difficult to understand, as the term defines the function of the scribe. ${ }^{88}$ I therefore suppose that this term,

84. Edited by Stutterheim (1925: 59-60) and again by Boechari (1985-86: 121-122). 85. Reading by Boechari published in Edi Sedyawati 1994: 325.

86. Edited by Titi Surti Nastiti (2007).

87. This passage is found among the unpublished archives in preparation of a corpus of inscriptions of the reign of Sinḍok that De Casparis was working on in the years before his death, and that are preserved in the Kern Institute collection at Leiden University Library.

88. I have not been able to trace the publication where De Casparis found the translation "terwille van het gewin". The reference to p. 59 is that of the page where Stutterheim 
originally an ablative formation, has been lifted from a Sanskrit context and used as a noun in the meaning of accountant or treasurer of a monastery or temple. The committees controlling the financial affairs of such institutions must each have had a treasurer for the income and expense, as is well known from the South Indian and Srilankan religious institutions. [...]. ${ }^{89}$ In the present case the R. Kanuruhan not only issues the edict but also keeps some financial control of the new foundation.

In her publication of the Sobhamerta inscription (no. 4), Titi Surti Nastiti (2007: 25, n. 60) noted:

Seperti yang dijelaskan oleh Christie dalam naskah yang diberikan kepada penulis, di dalam kamus Zoetmulder arthahetoh berarti untuk kepentingan seseorang, oleh sebab itu Christie membandingkan kata arthahetoh dalam prasasti Hara-hara (888 S/966 M), prasasti Wurudu Kidul (844 S/922 M), dan prasasti Hrin (856 S/934 M). Dalam prasasti Hara-hara disebutkan arthahetoh i Buddhiwala; dalam prasasti Hrin (856 S/934) disebutkan sebagai bagian dari titel sang Prasantamatih yang mengepalai sebuah wihara; dalam prasasti Wurudu Kidul disebutkan arthahetoh dàn= ácāryya $i$ Grih. Oleh karena itu Christie tidak menerjemahkan kata arthahetoh. Sedangkan Boechari menerjemahkan arthahetoh dengan bernama. Beliau menerjemahkan mpunkku i Nerañjanā arthahetoh boddhiwala dengan Mpungku dari Nerañjana bernama Boddhiwala (Sumadio 1984:169)..$^{90}$ Menurut pendapat penulis terjemahan kata arthahetoh dengan bernama dapat diterapkan dalam prasasti ini.

But Boechari had on an earlier occasion (1975: 83-84 / 2012: 242-243) interpreted the final phrase of the Wurudu Kidul inscription, likhita tambra arthahetoh dạn ācāryya i grih prāmodyajāta, as follows: "Rupa-rupanya ada seorang pendeta dari desa Grih yang bernama Prāmodyajāta yang merasa perlu untuk mengutip kedua keputusan itu di atas tembaga" - here, the words "yang merasa perlu" seem to be an attempt to paraphrase arthahetoh. Sarkar (1970-71, vol. II: 204) translates arthahetoh in this same sentence as "against the payment of money".

Clearly, none of the quoted scholars was aware of the technical usage of the word arthahetoh in Buddhist vinaya literature. See the long note of Nolot (1991: 388-390) on the expression arthahetoh ... näma grhnāmi, conveniently accessible even to a non francophone readership in the English summary of her work (pp. 530-531), from which I cite:

The phrase arthahetor nāma gṛhnāmi actually means, quite normally, « I mention the name because of the present circumstances $»$, and expresses a pan-Buddhist (and pan-Indian) reluctance to pronounce the name of a revered person [...].

\section{(1925) edits the plate in question, but no translation is joined to that edition.}

89. De Casparis here inserts a reference without page specification to Gunawardhana 1979.

90. The reference here is to volume II (Jaman Kuna), edited by Bambang Sumadio, of Sejarah Nasional Indonesia. I do not have access to the 1984 printing cited by Titi Surti Nastiti, but find the same words on the same page in the cetakan ke-6, edisi ke-4 of 1990. 
Among the epigraphic occurrences in Old Javanese listed above, the Kanuruhan inscription (no. 2) contains no explicit trace of religious affiliation, and the fact that it is engraved on the back slab of a Ganeśa statue might indicate that the context here is not Buddhist. The Wurudu Kidul inscription (no. 1) is not explicit about any religious affiliation either, but the name Prāmodyajāta is nevertheless a sure indicator that the one who bore it was a Buddhist. ${ }^{91}$ The two remaining inscriptions are both explicitly Buddhist. Although the evidence is not entirely unquivocal, it is not incompatible with the hypothesis that the use of the word arthahetoh in our inscription is another instance of specifically Buddhist terminology, this expression serving to preempt any offense that might be caused by designating a respected Buddhist master with his name.

This hypothesis is only slightly complicated by the occurrence of the same word in at least one Old Javanese literary source, where any direct Buddhist connection is out of the question. The passage is found in the Brahmāndapurāna (pp. 64-65):

anugraha rahadyan sañhulun mata sira; makasākși rama rahadyan sañhulun arthahetoh namaskāra bhatțāra brahmā an tinarimakən de rahadyan sanhulun ri sira $a^{92}$

'may he be granted eyes by milord; taking as witness milord's father, Lord Brahmā (by name, mentioned only) for the practical purpose of obeisance, (as to the fact) that they have been given by milord to him.'

I imagine that the usage we see in this literary text may have been adopted (and adapted, by insertion of the word namaskära) from the kind of contexts seen in the quoted inscriptions, where the arthahetoh applies to men of religion who can, in all but one instance, be identified without doubt as Buddhists. We may be dealing with a case of influence from Buddhist scribes on the literary language as a whole. The case would then be analogous to the influence exerted "behind the scences" by Buddhist parties on chancery language in first-millennium India identified by von Hinüber (2013).

\section{Relevance to economic history}

In the context of debate about the colonial government's agrarian legislation (Agrarische Wetgeving) of 1870, Kern (1911) drew attention to

91. See Edgerton 1953, Dictionary, under prāmodya.

92. Is it necessary to emend anugrahana? Gonda's text edition (1933) gives arthahetor, but I have changed this to arthahetoh, as we find in the inscriptions, because Gonda informs us on p. 247: "arthahetor, vgl. Bmḍ. Pur. 1, 13, 58 abravid vacanam devi namaskrtya Svayambhuve. De beide woorden $a_{r t h}^{\circ}$ nam $^{\circ}$ zijn m.i. als citaat op te vatten, al is het onzeker welke buigingsuitgang aan $\operatorname{nam}^{\circ}$ is toe te kennen. De hss. hebben arthahetoh". Zoetmulder probably failed to record this occurrence of arthahetoh in OJED because Gonda's edition prints the words arthahetor namaskāra as though they were lemmata from the Sanskrit text - comparison with the Sanskrit Brahmāndapurāna (1.13.58-66) shows that they are not. 
this inscription, even before its text was published, for its relevance to the history of land ownership in Java. ${ }^{93}$ A century later, it was used by Wisseman Christie in her "Preliminary notes on debt and credit in early island Southeast Asia" (2009). One of the points of interest of this inscription indeed lies in the light it casts on economic transactions in ancient Java and notably on the role that pawns (sanda) played in the endowment of religious establishments The relevant passage must first be quoted again (this time in normalized and emended form):

ya tekā pinunyakənira ... pakənanya gavayənnira kuṭi, dharma lpas kapodgalikanani kulasantānānira mpunku iñ nairañjanā, kunañ kramanya, ikañ savah kidul in̉ kuti, təmpah, 3, ya ta sinaṇḍa mpuñku susuk pagər, muañ mpun̉ku in nairañjanā, ìn mā kā 2, ya ta dharma mpunku, in susuk pagər, muan் mpuńku in nairañjanā, an paminta ika ləmah tumpal ika savah lor damələnira kuți, ya ta kāraṇanyan tinəbus lkañ savah saṇḍanira mpu mano, in mā kā 3, mapakəna bhuktyana sañ hyan kuṭi

“That is what he made a meritorious donation ... to serve for the monastery $(k u t i)$ to be made by him (Mpu Mano): the tax-exempt foundation (dharma) that is to be individual property of the lineage of the Master of Nairañjanā. As for its details: the wet-rice field south of the monastery (kuti), [measuring] 3 tompah, had been taken in security by the Master of Susuk Pagər and Master of Nairañjanā for 2 $k \bar{a} t i$ of gold. That (field) was the foundation of the Master of Susuk Pagor and Master of Nairañjanā, who (an) requested a border land, the wet-rice field to the north, (to be used) for his (Mpu Mano's) founding of a monastery. That is the reason why the wet-rice field given in security by Mpu Mano was redeemed by him for 3 katti of gold, to serve for being used as resource by the Holy Monastery $(k u t i i), \ldots$ '..

I tentatively interpret the chain of transactions to be intended as follows:

1. Mpu Mano (A) wishes to endow a monastery to become property of the Master of Susuk Pagər and Nairañjanā (B) and his descendants.

2. A wet-rice field south of the monastery had been pawned by A to B against 2 kātis of gold.

3. It is used by B to make a foundation of his own.

4. B requests other land to be used for A's foundation of a monastery.

5. A pays B 3 kătis to redeem the land he had pawned to B.

6. The whole sum of 3 kātis (or at least the difference, so $1 k \bar{a} t i$ ) is itself made object of donation to serve as resource for the newly founded monastery.

Other scenarios are possible, depending on how the word an and some of the instances of the pronominal suffix -nira are interpreted. However far we stretch our imagination, it seems to me impossible to be sure about any particular scenario, because the language of the text is simply too ambiguous. But if the $O J E D$ entry "anạ̣da, sinaṇda, kasạ̣da to take st. in security"

93. "Wanneer iemand woeste gronden, die hij uitdrukkelijk zegt van zijn voorouders als kindsdeel geërfd te hebben, vrijelijk wegschenkt, moet hij toch als eigenaar in den volsten zin des woords beschouwd worden" (Kern 1911: 199). 
is reliable, it seems difficult to interpret the transaction as it has been by Wisseman Christie (2009: 47):

The text records a substantial meritorious gift made by an individual donor to a sanctuary, part of which involved the redemption of land that had previously been pawned for the benefit of that religious foundation. This land, which had been pawned for 2 kati (1536 grams) of gold, was redeemed, on behalf of the sanctuary, at the cost of 3 kati (2304 grams) of gold, the additional kati of gold presumably representing the interest on the loan for which the pawned land acted as pledge.

For this interpretation requires translating sinand $\bar{a}$ as 'pawned', i.e., 'given in security', which is the opposite meaning of the one indicated by OJED. I am therefore a bit skeptical with regard to the conclusions that Wisseman Christie thought she could draw (ibid.) from a group of just three inscriptions, including the one that concerns us here:

Four points of interest arise from this small group of inscriptions. The first is the fact that, in at least one case, ${ }^{94}$ the cost of redemption of the land was apparently greater than the original sum loaned to the person who pawned it. This indicates that profit in the form of interest was expected from the loan, over and above that derived from the creditor's right to use the land. The second point is the fact that religious establishments, like individuals and communities, apparently borrowed substantial sums of money. The third point is that a serious argument could be mounted in court over the ownership of land allegedly pawned three centuries earlier. This suggests that the ownership of land in pawn did not automatically lapse after a set period of time. The fourth point is that there were apparently, by the fourteenth century, a number of existing law codes and a considerable body of customary law to be consulted by judges in such disputes.

Renewed study of the juridical texts from which most of the textual evidence underlying the relevant set of entries in $O J E D$ has been taken by Zoetmulder, as confronted both with the sanda-related data from some unpublished texts of the same genre ${ }^{95}$ and with new epigraphic evidence still unpublished at this time, may give reason to revise the dictionary and perhaps confirm Wisseman Christie's interpretation. But until such a comprehensive study is undertaken, it seems that any conclusions for economic history based on this inscription should be treated with circumspection.

Let me conclude this discussion by presenting the most important new piece of epigraphic evidence that I am aware of at this time. The passage in question, which requires much more commentary than I can give here, is found in the unpublished Patitihan charter issued by Krtanagara. I cite it from my forthcoming edition, along with a tentative translation that attempts to retain the meanings for forms derived from the base sanda as they are indicated in the dictionary: ${ }^{96}$

94. The single case intended here is precisely the one at issue in the present section. 95. For instance, the unpublished juridical text that is often, though erroneously, referred to as Svarajambu in the secondary literature (the correct reading is Svayambhu but this is not actually the title of the work), currently being edited and translated by Timothy Lubin and myself, contains a substantial passage on sanda.

96. A private collector holds four plates of this charter, which in its original state 
muvaḥ tu/ru\nyānugraha śrī mahārāja, Irikam baṇigrāma rim patitihan·, ri (5r4) sdananyāna sanda-sandanikam banigrāma rim patitihan salviranya, An titam ${ }^{97}$ tahun ·, tigam lèk', tigạm vñi kamnä ya LL(5r5)ba, yan tapvan panivō manisyani kalăntara, ndan mājara tam baṇigrāma rim̄ patitihan rumuhun ri sam masanda, yan tan anga (5r6) sam masaṇ̣a manbusa mvam tan paveha kālăntara, Iríka yan LLba, mvam pivruhakna ta rim vvań akveh, lāvan· yan hana saß(5v1)ṇ̣a katarival-, yan mās', vinujuran ${ }^{98}$ savrattya, yan karavam, sinalakan savrattya, yan. ratna holyana sabatavasa(5b2)nanyan sumanda, muvah yan hana drvya Ulihnim manilih salviranya, saṇdakna ta ya denikäm maniliḥ, dvaLn $\cdot$ kunəm, $\mathrm{sa}[\dot{\mathrm{m}}] \mathrm{ka}(\mathbf{5 v 3})$ ri lavasnikam drvya tan muliḥ denikam manilih makadivaśam rvam tahun', pjaha tekam ${ }^{99}$ manilị̆ nuni-nuni pjahana denika sam (5v4) panilihan', tan dampulana tekam drvya, An təbusən sakavvit denikam panilihan', kunəm yan ahurip ikam ma(5v5)nilih, sikəpən ta ya de sam panilihan', srahakna ri sam patitihan katəmvanim drvya, dampulana Ikam drvya, Apan ta(5v6)n (ma)lim Ikam mankkana, mańkana tekam drvya vinkasakən· mvam drvya pinarcchayakən', salvirnikam drvya sinilih lviranya, [... plate 6 unavailable ...] (7r1) yan hana doṣanika saṁ masaṇ̣ā denim deśa, luñhā teka sami masaṇ̣ā, gumantyānisyana takər turun· teka maş(7r2)naṇ̣̣ā yan mākārmmātitị̣ ...

'And the descent (i.e., concrete form?) of the grant of the Great King to the merchant guild of Patitihan, while the merchant guild of Patitihan holds all kinds of pawns, is that three years, three months, and three nights [should pass] before [the pawns] be forfeit if [the pawner] does not attentively comply with the interest (kalāntara). ${ }^{100}$ But the merchant guild at Patitihan should first make an announcement about the pawner, that the pawner is both unwilling to redeem and to furnish interest, [and] then that it will be forfeit, and it will be made known to many people. Moreover, that there is a (5b) pawn that has been lost; that gold has been sprinkled over (vinuvuran) so that it is similar in appearance (savrttya); that filigree (karavan) has been silvered so that it is similar in appearance (savrttya); that a jewel is to be replaced equal to its price (batavasan) when they took it as pawn.

And if there is property that results from borrowing anything, it may be pawned by the borrower. It may even be sold, on the grounds of the duration of [holding] property that does not revert from $(d e)$ the borrower for as long as two years. If the borrower should die, and certainly if he should be killed by the lender, that property should not be confiscated so that the whole principal can be redeemed by the lender. And if the borrower lives, [the property] should be seized by the borrower [and] what is found of the property should be handed over to the Patitihan. The property should be confiscated, for one like that is not a thief. Property left behind and property given in trust are like that: all types of borrowed property will be of its kind.

(7a) If the pawer should be at fault vis-à-vis (de) the district (deśa), the pawner leaves. The pawnee takes over fulfilling the takar turun (tax) when he works as fighter (?, atitih).

would have formed a set comprising at least ten plates. Alas plate 6 is unavailable. 97. Emend tigam.

98. Emend vinuvuran.

99. Emend pvekam?

100. It results from Timothy Lubin's and my research on the text referred to in $n .95$, and from consultation of standard Sanskrit dictionaries, that the entry kālantara in $O J E D$ is in need of correction. The Sanskrit term kalāntara (with $k a$, not $k \bar{a}$ !) means 'interest'. This meaning seems to fit in all of the Old Javanese contexts cited in OJED and in those known to me from unpublished sources. 


\section{Excursus on the dating of the Kancana and Kuti inscriptions}

In $\S 6.1$, I have presented textual material from the Kancana inscription (no. 4) and assigned to it a 10th-century date. In doing so, I have gone against the current communis opinio, because I am persuaded by the arguments offered more than a century ago by Krom (1914, Ep. Aant. VIII) concerning the date of this inscription. ${ }^{101}$ Recording a grant by king Srī Bhuvaneśvara Viṣnusakalātmakadigvijayaparākramottungadeva Lokapālalāñchana and dated to 782 Śaka, this text contains many elements that would be highly anomalous for a grant issued in the Śaka 700s while they would agree well with what we find in original issues of the Śaka 800s. Krom proposes that the king in question can be identified with the Lokapāla, father of Śrī Makutavaniśavardhana, figuring in Sanskrit stanzas VIII through IX of the Pucangan inscription issued by Airlanga in 963 Śaka, and tentatively suggests that the year 782 engraved at the start of the inscription could have been an inversion for 872 .

I have trouble understanding why Damais (1955: 26 n. 1) felt confident that he could ignore Krom's general arguments in favor of a date in the 10th century CE while also ignoring the possible link with the Pucangan inscription and opposing, against Krom's more specific hypothesis of inversion 782 for 872 , only the observation that "Les données ne sont réductibles qu'en gardant le millésime du texte, soit 782 śaka". Damais wanted the date 782 to be correct because he had decided in an earlier publication (1949: 1-6) to include it as an element in his dossier establishing the existence of a king called Lokapāla in the Śaka 700s.

It is possible to retort that the dating elements which Damais took to confirm the date in 782 Śaka may well have been calculated a posteriori for that year, and this is precisely the kind of situation that Amrit Gomperts seems to have had in mind when he wrote (2001: 123):

Calendar conversion of the Old Javanese calendar is essentially nothing more than a computational check on the consistency of all calender and other jyotisa $a$ elements. Indo-Javanese astrologers were mathematical craftsmen skilled in calculating time. They could easily falsify any day from a remote past into a perfectly consistent date in the Indo-Javanese period (A.D. 700-1500), as, for example, may be the case where the copper plates of Kuti are concerned (...).

Somewhat surprisingly, the parallelism between the Kancana case and that of the Kuti inscription, mentioned here by Gomperts, seems never to have played a role in the evaluation of the issue of dating the former, and was indeed not used by Krom himself, because he was convinced that the Kuti inscription

101. See also Krom 1931: 221-222, 224. 
is spurious. ${ }^{102}$ This idea is still found expressed in recent scholarship, ${ }^{103}$ even though Damais himself (1955: 19-20 n. 2) had elaborately and convincingly argued against it. Now the Kuti inscription is a grant of king Śrī Lokapāla Harivańśottungadeva bearing the date 762 , convertible almost as flawlessly as the 782 date of the Kancana inscription. Despite his demonstration that the date is basically convertible, and despite his arguments against rejecting the inscription as spurious, Damais arbitrarily rejects this king Lokapāla as an anachronism (1949: 6, 1955: 20) while he does not reject the similarly named king in the similarly dated Kancana grant.

A clinching argument in favor of Krom's hypothesis regarding Kancana, and for applying the same reasoning also to the Kuti inscription, comes from the passage where the latter mentions the children of king Lokapāla (lines $2 \mathrm{v} 2-3)$ :

hana tha vkanira pāduka śrī mahāraja, mañaran sira cañcu makuța, sira cañcu manggala, sira cañcu makuṭa, an̉her in kuṭi kulvan, sira cañcu mangala, an̉her in kuti vetan

'His Majesty the Great King had children, the one with the famous name Makuta (and) the one with the famous name Mangala. The one with the famous name Makuta dwelt in Kuṭi West (and) the one with the famous name Mangala dwelt in Kuți East.'

In my view, it cannot be a coincidence that stanzas VII-IX of the Pucangan inscription clearly state Airlanga's ancestor Makuțavańśavardhana to have been the son of Lokapāla. I therefore propose,

1. to consider that the nearly synonymous titles Śn̄ Bhuvaneśvara Viṣnusakalātmakadigvijayaparākramottungadeva Lokapālalāñchana (in the Kancana charter) and Śrī Lokapāla Harivańśottungadeva (in the Kuti charter) designated one and the same king;

2. to identify this king and his son Makuța with the Lokapāla and his son Makuțavańsavardhana of the Pucangan inscription, which situates these two persons respectively three and two generations before Airlanga, and from which we learn that Airlanga was sixteen years of age in 939 Śaka, which means that he was born around 923 Śaka; ${ }^{104}$

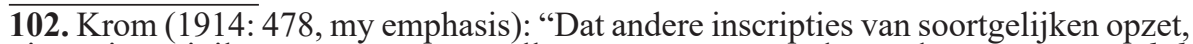
uitvoerige privileges, enz. geen van allen een zoo vroegen datum dragen - natuurlijk blijft de door Cohen Stuart uitgegevene van 762, waarvan Brandes overtuigend de onechtheid bewezen heeft, buiten beschouwing - kan aan het toeval te wijten zijn en behoeft dus geen argument te zijn tegen de vroege dateering. Toch verdient het de opmerking, dat in het algemeen alle bekende oorkonden uit de achtste en nog het begin der negende eeuw een veel eenvoudiger karakter dragen."

103. Gomperts (2001: 116): "The contents of the inscription appear fictitious as the dramatis personae never appear in Indo-Javanese history again." I will show below that this point about dramatis personae seems to be wrong.

104. See already Sarkar (1971-72, vol. I: 84/91, n. 25), on the name Cañcu Makuța: "This name reminds us of Mukuțavangśavarddhana, the son of king Lokapāla, who is 
3. to date the original issues of the Kuti and Kancana inscriptions well into the 10th century CE, i.e., after Śaka 850, and to consider the dates 762 and 782 Saka engraved on the Majapahit-period reissues as spurious. ${ }^{105}$

It does not seem entirely impossible that the original dates would have been altered only for the century, and were precisely 862 and 882 , because nothing precludes the hypothesis that our 10th-century king Lokapāla was sovereign ruler over territory independent of that ruled by his father-in-law Sindok - whose latest inscription (Muncang) is dated to 866 Śaka. But it is perhaps slightly more likely that both inscriptions belong to the Śaka 880 s, as does Mpu Mano's. ${ }^{106}$

\section{Conclusions}

I hope to have shown how important it is to go and seek out Old Javanese inscriptions, whether they are kept in Museums or can be found in the field, because the reliability of the historical data that we extract from any inscription depends on a chain of interpretation that is only as strong as the reliability of every step beginning with our decipherment of the text. Several inscriptions considered lost are waiting to be rediscovered, while some others that have simply not been studied at all are waiting to be documented, read and analyzed.

The rediscovery of the plate that has been the focus of this article has made it possible to act upon Boechari's instigation in the quote with which I started. Rereading the Mpu Mano inscription more than 100 years after Brandes' 19 th-century reading of it was published has yielded 19 improvements of

referred to in the so-called Calcutta stone-inscription of Airlangga...". The reading in stanza IX of the Pucangan inscription is actually -makuta-, not -mukuta-.

105. It might be objected that the appearance of the name Dakșot(t)ama immediately after that of the king in two passages of the Kuti inscription contradicts my proposal, for Dakșa, as is well known, was first Balitun's Minister of Hino and then succeeded Balitun to reign during the second decade of the 10th century. The first passage (plate $2 \mathrm{v}-3 \mathrm{r}$ ) is dinulur de rakryan mahāmantri katrini, rakryan mantri hino, daksotama, rakryan. mantri halu, pratipakșasańśàya, rakryan- mantri sirikan., mahāmāhino, while the second (plate 10r) is yan hana vvam lumañghānani Ajjũannira

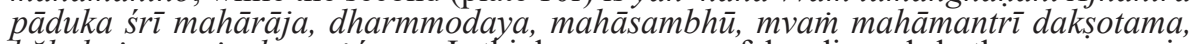
băhubajrapratipakșasaniśaya. I think we can safely discard both passages in attempting to date the original issue of the Kuti charter, because the text has quite obviously been distorted in the first passage, parts of Dakșa's well-known titulature (mahāmantrī hino pu dakșottama bāhubajra pratipakșakșaya) being redistributed to supply the names of the three Great Ministers. I assume that an attempt was made at the time of the charter's reissue to rewrite the text in order to create the impression that it has originally been issued by Balitun, by a person who was apparently unaware or did not care that the date 762 Saka would be incomptabible with original issue during Balitun's reign.

106. It should be noted that I am assuming the authenticity of the year 888 Saka engraved on it, although we know that other parts of the date of this inscription are the result of manipulation at the time of reissue. See $\S 4$ above. 
reading, a small handful among them significant. ${ }^{107}$ The result is a text in generally clear Old Javanese, unmarked by most of the errors and confusions that one might be led to expect by reading what our predecessors in Old Javanese epigraphy have written with regard to the fidelity of Majapahitperiod reissues of earlier grants, called tinulad in the Indonesian-language scholarly literature. We often find such qualifications as "erroneous", "revised" or "confused" applied to such reissues. ${ }^{108}$ It seems that at least the present inscription was a particularly faithful copy of its original, for evident anachronisms are found only in the dating formula, and evident errors (which might have occurred in the copying process) are rather few. The photos now available have also allowed me to propose an unsually specific paleographic comparison that confirms Brandes' original suggestion that the reissue would have taken place in the 14th century, during the reign of Hayam Wuruk.

The process of translating even this short text has required reconsideration of the meaning of several headwords in the Old Javanese dictionary, and led me to propose revision of the meanings in more than one case. I have shown that the word hara-hara in the inscription is not a toponym and recommended that the inscription be designated henceforward after its main protagonist, $\mathrm{Mpu}$ Mano. In attempting to interpret the inscription, the fact that $\mathrm{Mpu}$ Mano wished to make merit by donating land to a Buddhist beneficiary has been an important guide, while I have tried to adopt a holistic approach to the problems of interpretation, taking into account both epigraphic and nonepigraphic evidence, including evidence in Sanskrit where it is relevant to the local history of Buddhism.

And this leads me to perhaps the most important implication of this study. The meritorious donation made by Mpu Mano is part of a noticeable spike in patronage of Buddhism in the middle and lower Brantas river in East Java during the second half of the 10th century - already noticed by Krom (1931: 219-221), and recently discussed again by Hadi Sidomulyo (2011: 129) corresponding to the reign of Sinḍok and his immediate successors, so Mpu Mano's donation must be regarded in this context. Other epigraphical traces of

107. See above, notes $14,30,31$ and 32 .

108. See Damais 1952: 10 n. 2 for a collection of Dutch qualifications used in the scholarly literature; see also Boechari 2012: 9 ("Kekacauan semacam itu sering kali terjadi apabila kita dihadapkan kepada prasasti tinulad yang ditulis beberapa abad sesudah prasasti aslinya"), $75 \mathrm{n}$. 11 ("tetapi prasasti itu jelas tinulad; menurut bentuk hurufnya mungkin sekali dibuat dalam zaman Majapahit, sehingga tidaklah mengherankan apabila di dalam prasasti itu terdapat istilah yang biasa terdapat dalam prasasti-prasasti dari masa yang lebih muda"), 93 n. 43 ("Prasasti itu jelas tinulad, sehingga pencampurbauran gelar Siṇ̣ok dan Dakșa itu sebenarnya tidak perlu dibicarakan, sebab mungkin sekali si penyalin berhadapan dengan prasasti asli yang sudah sangat usang, dan ia menambahkan saja gelar yang terlintas dalam ingatannya (cf. Damais, 1955b:181, catatan no. 3)". See for further references the index entries 'tinulad' and 'copy' in Boechari 2012. 
this spike have been listed in $\S 6.1$ (no. 4) and $\S 6.5$. In my $\S 8$, I have restored two important inscriptions to their rightful place in this dossier. ${ }^{109}$ This epigraphic evidence can in turn be linked with other archaeological evidence of Buddhism in this area in the same period, such as the Muteran hoard and the finds at Candi Gentong (both at Trowulan), or the important hoard of bronze sculptures found in the village Candirejo in Nganjuk regency (where the Hering inscription originates as well); ${ }^{110}$ and it can perhaps be linked also with the issue of the dating of some of the Buddhist texts transmitted on Bali, associated (albeit unhistorically) in scholarship with the title San Hyar Kamahāyanikan, for mention is made in rare manuscripts of a "noble guru in Vañjan", a sima "which was an offering to this master (guruyāga)" by king Sindok. ${ }^{111}$ The Deśavarnana (78.8) lists Vañjan as one of the main Buddhist sanctuaries in Java but the site has to my knowledge not yet been identified. Perhaps a problem that future investigation of the history of Buddhism in this period and area will be able to solve!

\section{References}

\section{Editions and translations of primary sources}

Designations of inscriptions are simplified to conform to the spelling of Indonesian (Ejaan yang disempurnakan), so I spell, e.g., Sobhamerta instead of Śbhāmrta, etc. Inscriptions cited without reference to any edition are quoted from editions that can be identified via Nakada (1982). For inscriptions published since Nakada's time, I refer to the relevant edition. The following editions have been used for citing non-epigraphic primary sources:

$\bar{A}$ diparva

Agastyaparva

Bhīsmaparva

Brahmānḍapurāna

Deśavarnana

Kuñjarakarṇa Dharmakathana

Navaruci

Rāmāyaṇa

Uttarakānda
Juynboll 1906

Gonda 1933a

Gonda 1936

Gonda 1933 b

Pigeaud (1960-63, vol. I)

Teeuw \& Robson 1981

Prijohoetomo 1934

Kern 2015

Zoetmulder 2006

109. On the grounds that the foundation is called kuti, I assume that we are dealing in the case of Kuti with a grant in favor of a Buddhist establishment, although the rest of the inscription is silent as to its religious affiliation. Cf. above, §6.4.

110. On the Muteran hoard and its 10th-century dating, see Lunsingh Scheurleer 2005; on the Buddhist finds at Candi Gentong, see Titi Surti Nastiti 2015; on the Candirejo finds, see Fontein 1990: 231-233.

111. I quote from Hudaya Kandahjaya 2016: 93. This author believes the passage is attested in only one manuscript (kept at Leiden), but I have found it also in a transcript of the lontar IIIB. 246 belonging to the collection of the Kirtya in Singaraja, Bali. 


\section{Secondary sources}

Acri, Andrea. 2017. Dharma Pātañjala: A Śaiva Scripture from Ancient Java, Studied in the Light or Related Old Javanese and Sanskrit Texts. Second Edition. Sata-Pitaka Series 654. New Delhi: International Academy of Indian Culture and Aditya Prakashan.

_2018. Dharma Pātañjala: kitab Śaiva dari Jawa zaman kuno, kajian dan perbandingan dengan sumber Jawa Kuno dan Sanskerta terkait. Translated by Arif Bagus Prasetyo. Naskah dan dokumen Nusantara 36. Jakarta: Kepustakaan Populer Gramedia; École française d'Extrême-Orient.

Acri, Andrea, and Arlo Griffiths. 2014. "The Romanisation of Indic Script Used in Ancient Indonesia.” Bijdragen Tot de Taal-, Land- En Volkenkunde 170 (2/3): 365-78. https://doi. org/10.1163/22134379-17002005.

Balogh, Dániel, and Arlo Griffiths. 2019. "Transliteration Guide for Members of the DHARMA Project." https://halshs.archives-ouvertes.fr/halshs-02272407.

Bambang Sumadio, ed. 1990. Sejarah Nasional Indonesia. 4th edition, 6th printing. Vol. II. Jakarta: Balai Pustaka.

Bambang Sumadio, and Endang Sri Hardiati, eds. 2008. Sejarah Nasional Indonesia. Edisi pemutakhiran. Vol. II. Jakarta: Balai Pustaka.

Boechari. 1977. "Epigrafi dan sejarah Indonesia.” Majalah Arkeologi 1 (2): 1-40. 1985-86. Prasasti Koleksi Museum Nasional, Jilid I. Jakarta: Proyek Pengembangan Museum Nasional, Departemen Pendidikan dan Kebudayaan.

. 1986. "Perbanditan di dalam Masyarakat Jawa Kuna." In Pertemuan Ilmiah Arkeologi IV, Cipanas, 3-9 Maret 1986, IV. Manusia-Lingkungan Hidup-Teknologi, Sosial-Budaya, Konsepsi-Metodologi:159-96. Jakarta: Proyek Penelitian Purbakala / Departemen Pendidikan dan Kebudayaan.

2012. Melacak sejarah kuno Indonesia lewat prasasti / Tracing ancient Indonesian history through inscriptions. Jakarta: Kepustakaan Populer Gramedia (KPG); Departemen Arkeologi, Fakultas Ilmu Pengetahuan Budaya, Universitas Indonesia; École française d'Extrême-Orient.

Brandes, J.L.A. 1913. Oud-Javaansche oorkonden: nagelaten transcripties. Edited by N.J. Krom. Verhandelingen van het Bataviaasch Genootschap van Kunsten en Wetenschappen, 60 (parts 1 and 2). Batavia; 's-Hage: Albrecht; Nijhoff. https://archive.org/details/ verhandelingenv601913bata.

Casparis, J.G. de. 1978. Indonesian Chronology. Vol. 1. Handbuch der Orientalistik. 3. Abt., Indonesien, Malaysia und die Philippinen 1. Leiden: Brill.

Damais, Louis-Charles. 1949. "Epigrafische aanteekeningen." Tijdschrift voor Indische Taal-, Land-en Volkenkunde 82: 1-26.

1950. "Les formes de politesse en Javanais moderne." Bulletin de la Société des études indochinoises 25 (1): 265-80.

_. 1955. "Etudes d'épigraphie indonésienne, IV: Discussion de la date des inscriptions." Bulletin de l'Ecole française d'Extrême-Orient 47 (1): 7-290.

Eade, J.C., and Lars Gislén. 2000. Early Javanese Inscriptions: A New Dating Method. Handbuch der Orientalistik. 3. Abt., Südostasien 10. Leiden: Brill.

Edgerton, Franklin. 1953. Buddhist Hybrid Sanskrit Grammar and Dictionary. 2 vols. William Dwight Whitney Linguistic Series. New Haven: Yale University Press.

Edi Sedyawati. 1994. Ganeśa Statuary of the Kadiri and Sinhasāri Periods: A Study of Art History. Verhandelingen van het Koninklijk Instituut voor Taal-, Land- en Volkenkunde 160. Leiden: KITLV Press.

Fontein, Jan. 1990. The Sculpture of Indonesia. Washington: National Gallery of Art; Abrams.

Gomperts, Amrit. 2001. "Sanskrit Jyotișa Terms and Indian Astronomy in Old Javanese Inscriptions." In Fruits of Inspiration: Studies in Honour of Prof. J.G. de Casparis, Retired Professor of the Early History and Archeology of South and Southeast Asia at the University of Leiden, the Netherlands, on the Occasion of His 85th Birthday, edited 
by M.J. Klokke and K.R. van Kooij, 93-133. Gonda Indological Studies 11. Groningen: Egbert Forsten.

Gonda, Jan. 1933a. "Agastyaparwa, een oud-javaansch proza-geschrift." Bijdragen tot de Taal-, Land- en Volkenkunde 90: 329-419. https://doi.org/10.1163/22134379-90001420.

1933b. Het Oud-Javaansche Brahmānda-Purāna: proza-tekst en kakawin. Bibliotheca Javanica 5. Bandoeng: Nix.

- 1936. Het oudjavaansche Bhīṣmaparwa. Bibliotheca Javanica 7. Bandoeng: A.C. Nix \& Co.

1973. Sanskrit in Indonesia. $2^{\text {nd }}$ edition. Śata-Pițaka Series 99. New Delhi: International Academy of Indian Culture. ( $1^{\text {st }}$ edition 1952.)

Griffiths, Arlo. 2014. "Inscriptions of Sumatra, III: The Padang Lawas Corpus Studied along with Inscriptions from Sorik Merapi (North Sumatra) and from Muara Takus (Riau)." In History of Padang Lawas, North Sumatra, II: Societies of Padang Lawas (Mid-NinthThirteenth Century CE), edited by Daniel Perret, 211-53. Cahier d'Archipel 43. Paris: Association Archipel.

Gunawardana, R.A.L.H. 1979. Robe and Plough: Monasticism and Economic Interest in Early Medieval Sri Lanka. Monographs of the Association for Asian Studies 35. Tucson: published for the Association for Asian Studies by The University of Arizona Press.

Hadi Sidomulyo. 2007. Napak tilas perjalanan Mpu Prapañca. Jakarta: Wedatama Widya Sastra bekerja sama dengan Yayasan Nandiswara Jurusan Pendidikan Sejarah Unesa.

_ 2010. "From Kuṭa Rāja to Singhasāri: Towards a Revision of the Dynastic History of 13th Century Java." Archipel 80: 77-138. https://doi.org/10.3406/arch.2010.4177.

_. 2018. "Notes on the Topography of Ancient Java: Identifying Four Sima Territories from the Majapahit Period." In Writing for Eternity: A Survey of Epigraphy in Southeast Asia, edited by Daniel Perret, 223-41. Études Thématiques 30. Paris: École française d'Extrême-Orient.

Hinüber, Oskar von. 2013. "Behind the Scenes: The Struggle of Political Groups for Influence as Reflected in Inscriptions." Indo-Iranian Journal 56 (3-4): 365-79. https://doi. org/10.1163/15728536-13560304.

Hoogervorst, Tom. 2017. "Lexical Influence from North India to Maritime Southeast Asia: Some New Directions." Man in India 97 (1): 293-334.

Hudaya Kandahjaya. 2016. "San் Hyan் Kamahāyānikan, Borobudur, and the Origins of Esoteric Buddhism in Indonesia." In Esoteric Buddhism in Mediaeval Maritime Asia: Networks of Masters, Texts, Icons, edited by Andrea Acri, 67-112. Singapore: ISEAS - Yusof Ishak Institute.

Issatriadi. 1975. Laporan Sementara Penemuan Tiga Buah Prasasti di Daerah Ukir Negara Blitar. Surabaya: Museum Mpu Tantular.

Juynboll, H.H. 1906. Âdiparwa: Oudjavaansch prozageschrift. 's-Gravenhage: M. Nijhoff.

Kern, Hendrik. 1908. "Een Oudjavaansche oorkonde gevonden op de helling van den Kawi." Bijdragen tot de Taal-, Land- en Volkenkunde van Nederlandsch-Indië 60: 45-51. https:// doi.org/10.1163/22134379-90001908.

. 1911. "Mededeeling in de Koninklijke Akademie van Wetenschappen op 9 September 1907 over recht van privaateigendom op den grond op Java in de Middeleeuwen." In Adatrechtbundel I, bezorgd door de commissie voor het adatrecht, uitgegeven door het Koninklijk Instituut voor de Taal-, Land en Volkenkunde van Nederlandsch-Indië, 198200. 's-Gravenhage: M. Nijhoff.

. 1917a. "Over eene Oudjavaansche oorkonde (gevonden te Gĕdangan, Surabaya) van Çaka 782 (of 872)." In Verspreide Geschriften, 7:17-53. 's-Gravenhage: M. Nijhoff.

—. 1917b. "Een Oudjavaansche oorkonde gevonden op de helling van den Kawi (oostJava; \pm 850 Çāka).” In Verspreide geschriften, 7:176-85. 's-Gravenhage: M. Nijhoff.

. 2015. Rāmāyana: The Story of Rāma and Sìtā in Old Javanese. Edited by Willem van der Molen. Javanese Studies 1. Tōkyō: Research Institute for Languages and Cultures of Asia and Africa, Tokyo University of Foreign Studies. 
Krom, N.J. 1914. "Epigraphische aantekeningen, VIII: De dateering der oorkonde van Kancana, IX: De inscriptie van Prapancasarapura." Tijdschrift voor Indische Taal-, Landen Volkenkunde 56: 477-89.

-1931. Hindoe-Javaansche geschiedenis. Tweede, Herziene druk. 's-Gravenhage: Martinus Nijhoff.

Lokesh Chandra. 1995. "San் Hyan Kamahāyānikan." In Cultural Horizons of India, Vol. 4, 295-434. Śata-Pitaka Series 381. New Delhi: International Academy of Indian Culture and Aditya Prakashan.

Lunsingh Scheurleer, Pauline. 2005. "The Finds from Muteran and Wonoboyo." In Indonesia: The Discovery of the Past, edited by Endang Sri Hardiati and Pieter ter Keurs, 52-67. Amsterdam: KIT Publishers.

Machi Suhadi, and Richadiana Kartakusuma. 1996. Laporan Penelitian Epigrafi di Wilayah Provinsi Jawa Timur. Berita Penelitian Arkeologi 47. Jakarta: Proyek Penelitian Arkeologi Jakarta, Pusat Penelitian Arkeologi Nasional, Departemen Pendidikan dan Kebudayaan.

Molen, Willem van der. 1983. Javaanse tekstkritiek: een overzicht en een nieuwe benadering geïllustreerd aan de Kunjarakarna. Verhandelingen van het Koninklijk Instituut voor Taal-, Land- en Volkenkunde 102. Dordrecht: Foris.

Nakada, Kōzō. 1982. An Inventory of the Dated Inscriptions in Java. Memoirs of the Research Department of the Toyo Bunko 40. Tokyo: Toyo Bunko.

Nolot, Édith. 1991. Règles de discipline des nonnes bouddhistes: le Bhikṣunīvinaya de l'école Mahāsāmghika-Lokottaravādin - Traduction annotée, commentaire, collation du manuscrit. Publications de l'Institut de civilisation indienne 60. Paris: Collège de France; Édition-diffusion de Boccard.

Perret, Daniel, Machi Suhadi, and Richadiana Kartakusuma. 2003-04. "Le programme franco-indonésien d'inventaire des inscriptions "classiques" du monde malais." Bulletin de l'École française d'Extrême-Orient 90-91: 473-74. https://doi.org/10.3406/ befeo.2003.3621.

Pigeaud, Th.G.Th. 1960-63. Java in the 14th Century: A Study in Cultural History. The NägaraKèrtāgama by Rakawi, Prapañca of Majapahit, 1365 A.D. 5 vols. Koninklijk Instituut voor Taal-, Land- en Volkenkunde Translation Series 4. The Hague: Martinus Nijhoff.

Prijohoetomo. 1934. Nawaruci: inleiding, Middel-javaansche prozatekst, vertaling vergeleken met de Bimasoetji in Oud-javaansch metrum. Groningen: Wolters. https://resolver.kb.nl/ resolve?urn=MMKB05:000034071:pdf.

Robson, Stuart. 1995. Deśawarnana (Nāgarakrtāgama). Verhandelingen van het Koninklijk Instituut voor Taal-, Land- en Volkenkunde 169. Leiden: KITLV Press.

Sarkar, Himansu Bhusan. 1971-72. Corpus of the Inscriptions of Java (Corpus Inscriptionum Javanicarum), up to 928 A. D. 2 vols. Calcutta: Firma K.L. Mukhopadhyay.

Schopen, Gregory. 2001. "Dead Monks and Bad Debts: Some Provisions of a Buddhist Monastic Inheritance Law." Indo-Iranian Journal 44 (2): 99-148.

Stein Callenfels, P.V. van. 1924. "Stukken betrekking hebbend op Oud-javaansche opschriften in de Bibliothèque Nationale te Parijs." Oudheidkundig Verslag, Bijlage B: 23-27.

_. 1929. "Bijdragen tot de topographie van Java in de Middeleeuwen." In Feestbundel uitgegeven door het Koninklijk Bataviaasch Genootschap van Kunsten en Wetenschappen bij gelegenheid van zijn 150 jarig bestaan, 1778-1928, 2:370-92. Weltevreden: G. Kolff.

Stutterheim, W.F. 1925. "Transscriptie van twee jayapattra's." Oudheidkundig Verslag, Bijlage D: $57-60$.

Teeuw, A., and S.O. Robson. 1981. Kuñjarakarna Dharmakathana: An Old Javanese Poem. Bibliotheca Indonesica 21. The Hague: Nijhoff.

Titi Surti Nastiti. 2007. Prasasti Sobhämrta. Jakarta: Pusat Penelitian dan Pengembangan Arkeologi Nasional, Badan Pengembangan Sumberdaya Kebudayaan dan Pariwisata, Departemen Kebudayaan dan Pariwisata. 
2015. "Miniature Stūpas and a Buddhist Sealing from Candi Gentong, Trowulan, Mojokerto, East Java." In Buddhist Dynamics in Premodern and Early Modern Southeast Asia, edited by D. Christian Lammerts, 120-37. Singapore: Institute of Southeast Asian Studies.

Wibowo, A.S. 1979. "Prasasti Ālasantan tahun 861 Śaka." Majalah Arkeologi (diterbitkan oleh Lembaga Arkeologi FSUI) 2 (3): 3-51.

Wisseman Christie, Jan. 2009. "Preliminary Notes on Debt and Credit in Early Island Southeast Asia." In Credit and Debt in Indonesia, 860-1930: From Peonage to Pawnshop, from Kongsi to Cooperative, edited by David Henley and Peter Boomgaard, 41-60. Singapore: Institute of Southeast Asian Studies.

Zoetmulder, P.J. 1950. De taal van het Adiparwa: een grammaticale studie van het Oudjavaans. Reprint 1983. Dordrecht: Foris Publications.

1982. Old Javanese-English Dictionary. 's-Gravenhage: Nijhoff.
2006. Uttarakāṇda: teks Jawa kuna. Bibliotheca purbajavanica 2. Yogyakarta: Penerbit Universitas Sanata Dharma.

Zoetmulder, P.J., and I.R. Poedjawijatna. 1992. Bahasa parwa: tatabahasa Jawa kuna. 2 vols. Yogyakarta: Gadjah Mada University Press. 
